\title{
Impact of tectonic and volcanism on the Neogene evolution of isolated carbonate platforms (SW Indian Ocean)
}

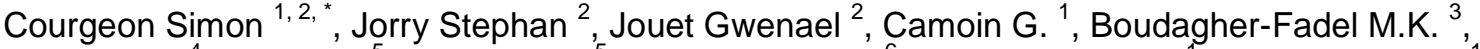 \\ Bachèlery P. ${ }^{4}$, Caline B. ${ }^{5}$, Boichard R. ${ }^{5}$, Révillon Sidonie ${ }^{6}$, Thomas Yannick ${ }^{1}$, Thereau Estelle ${ }^{1}$, \\ Guérin Charline ${ }^{1}$
}

${ }^{1}$ Aix Marseille Université, CNRS, IRD, Collège de France, CEREGE, Aix-en-Provence, France

2 IFREMER, Unité Géosciences Marines, 29280, Plouzané, France

${ }^{3}$ University College London, Earth Science, 2 Taviton St, London, WC1H 0BT, UK

${ }^{4}$ Université Clermont Auvergne, CNRS, IRD, OPGC, Laboratoire Magmas et Volcans, F-63000

Clermont-Ferrand, France

${ }^{5}$ TOTAL Exploration and Production, CSTJF, Avenue Larribau, 64000, Pau, France

${ }^{6}$ SEDISOR/UMR 6538, Laboratoire Domaines Océaniques, IUEM, 29280, Plouzané, France

*Corresponding author : Simon Courgeon, email address : simon.courgeon@gmail.com

\begin{abstract}
:
Understanding the impact of tectonic activity and volcanism on long-term (i.e. millions years) evolution of shallow-water carbonate platforms represents a major issue for both industrial and academic perspectives. The southern central Mozambique Channel is characterized by a $100 \mathrm{~km}$-long volcanic ridge hosting two guyots (the Hall and Jaguar banks) and a modern atoll (Bassas da India) fringed by a large terrace. Dredge sampling, geophysical acquisitions and submarines videos carried out during recent oceanographic cruises revealed that submarine flat-top seamounts correspond to karstified and drowned shallow-water carbonate platforms largely covered by volcanic material and structured by a dense network of normal faults. Microfacies and well-constrained stratigraphic data indicate that these carbonate platforms developed in shallow-water tropical environments during Miocene times and were characterized by biological assemblages dominated by corals, larger benthic foraminifera, red and green algae. The drowning of these isolated carbonate platforms is revealed by the deposition of outer shelf sediments during the Early Pliocene and seems closely linked to (1) volcanic activity typified by the establishment of wide lava flow complexes, and (2) to extensional tectonic deformation associated with high-offset normal faults dividing the flat-top seamounts into distinctive structural blocks. Explosive volcanic activity also affected platform carbonates and was responsible for the formation of crater(s) and the deposition of tuff layers including carbonate fragments. Shallow-water carbonate sedimentation resumed during Late Neogene time with the colonization of topographic highs inherited from tectonic deformation and volcanic accretion. Latest carbonate developments ultimately led to the formation of the Bassas da India modern atoll. The geological history of isolated carbonate platforms from the southern Mozambique Channel represents a new case illustrating the major impact of tectonic and volcanic activity on the long-term evolution of shallow-water carbonate platforms.
\end{abstract}

Keywords : Carbonate platform, drowning, volcanism, tectonic, Mozambique Channel 


\section{Introduction}

Understanding the processes controlling the long-term (i.e. millions to tens of millions year) evolution of shallow-water carbonate platforms represents a major scientific question and has been the subject of numerous studies over the last decades (e.g. Aubert and Droxler., 1992; Wilson et al., 1998; Wilson, 2000; Schlager, 2005; DiCaprio et al., 2010; Andrieu et al., 2016; Paumard et al., 2017; Pomar et al., 2017; Brandano et al., 2017). The onset, growth and demise of tropical carbonate platforms are controlled by numerous parameters including merely: (1) biota and skeletal grain production, (2) eustacy, (3) tectonics, (4) volcanism and (5), environmental conditions. However, active ongoing debates concern the respective impact of these factors on carbonate platforms development, as well as their possible interactions.

The development of shallow-water carbonate platforms in active tectonic settings frequently interacts with structural deformation. Faulting commonly leads to the segmentation of carbonate platform(s) into several structural blocks affected by distinct tectonicallyinduced vertical movements. A rapid increase in accommodation triggered by tectonic subsidence, and outpacing carbonate accumulation rates, is frequently involved in drowning processes affecting shallow-water carbonate platforms (e.g. Wu et al., 2014). In Sulawesi (Indonesia), Eocene tropical carbonate platforms were affected by extensional tectonic deformation responsible for local drowning in hanging wall areas and subaerial exposure on adjacent footwall highs (Wilson, 2000). Tilting (e.g. Menier et al., 2014) and differential 
tectonic subsidence (e.g. Lehrmann et al., 2007; Courgeon et al., 2016a) are commonly responsible for partial drowning and diachronous development of shallow-water carbonate platforms. Topographic highs inherited from structural deformation form suitable substrates for shallow-dwelling carbonate producers during the onset and/or backstepping of shallowwater carbonate platforms (e.g. Bachtel et al, 2004; Lü et al., 2013).

In active tectonic settings, tectonic deformations are often accompanied with volcanic activity which may impact the development of platform-dwelling biological communities (e.g. Wilson and Lokier., 2002; Houk, 2011): (1) products of volcanic eruptions (i.e. lava flows, volcaniclastic material) can physically smother carbonate producers and, eventually, bury them to death; (2) increased water turbidity induced by volcanic particles input decreases light penetration in the ocean, thus hampering the growth of light-dependent carbonate producers; these combined effects tend to reduce biological diversity, production rates and water-depth interval at which carbonate assemblages can develop; (3) Fluxes of volcaniclastic sediments frequently modify water chemistry (e.g. salinity, $\mathrm{pH}$ ) and increase nutrient content and surface-water productivity. While shallow-water carbonate producers poorly tolerate, for instance, salinity fluctuations, high nutrient concentrations tend to further promote the growth and activity of other heterotrophic organisms (e.g. Hallock and Schlager, 1986; Mutti and Hallock, 2003). Volcanic systems and associated vents can also release important amounts of gas that are susceptible to disrupt the development of shallow-water benthic carbonate producers (e.g. CO2, Hall-Spencer, 2008). Volcanism appears overall detrimental to contemporary and proximal shallow-water carbonate systems. In the geological record, several case studies link partly or fully shallow-water carbonate platform terminations to volcanic activity (e.g. Wilson, 2000; Lehrmann et al., 2007). Active volcanism during carbonate platform development can only induce a local and/or temporary interruption in carbonate sedimentation, as it is recorded by an intercalation of volcanic layers into carbonate 
deposits (e.g. Martin et al., 2004), explosive morphologies (e.g. Basile and Chauvet, 2009) or intrusive networks directly into carbonate accumulations (e.g. Fernandez-Mendiola and Garcia-Mondejar, 2003).

In parallel, shallow-water carbonate producers also demonstrate their ability to cope with sediment fluxes associated to volcanic activity. In SE Asia, peaks of volcaniclastic fluxes during the Neogene are marked by changes in type and morphology of biota (Wilson et Lokier, 2002). For instance, in volcaniclastic-rich deposits, preserved benthos were dominated by mobile organisms (e.g. mollusks and solitary corals) able to self-extract if covered by small amounts of sediments. In Indonesia, reef communities recover promptly (i.e. within 5 years) after effusive eruptions through the colonization of lava flows (Tomascik et al., 1996). Disturbances caused by volcanic activity are usually limited to carbonate systems close to the volcanic center(s) (e.g. Wilson., 2000; Lehrmann et al., 2007) and are modulated by the nature and intensity of the eruptions. Accordingly, a shallow-water carbonate system can normally develop along with volcanic activity if it evolves distally and/or protected from eruptive center(s).The impact of tectonic activity and volcanism on long-term carbonate platform development remains poorly understood and new case studies are needed to tackle that issue.

In the Indo-Pacific realm, many tropical isolated shallow-water carbonate platforms settled on volcanic substrates, flourished throughout the Cenozoic and locally kept on developing to form modern atolls (e.g. Maldives; Belopolsky and Droxler., 2004; Enewetak and Bikini atolls; Lincoln and Schlanger, 1991). However, studies reporting the evolution of carbonate platforms characterized by both tectonic and volcanic activity are very rare. Isolated carbonate platforms provide the opportunity to better assess interactions between carbonate sedimentation and tectonic/volcanic activity as they are not exposed to terrigenous inputs. In the southern central part of the Mozambique Channel (MC), a $100 \mathrm{~km}$ long volcanic ridge 
hosts both Neogene drowned shallow-water carbonate platforms and a modern atoll. These isolated carbonate systems are affected by well-developed fault networks, and drowned flattop levels exhibit widespread volcanic morphologies (Courgeon et al., 2016b). Based on the study of multi-resolution seismic data set, high resolution bathymetry DEMs, submarine videos and dredged samples, this study aims at: (1) describing architecture, age and nature of drowned carbonate platforms, (2) characterizing volcanic and tectonic activity that affected these isolated carbonate systems, and (3) proposing a conceptual model to explain different platform evolutions by discussing, especially, the interactions between carbonate sedimentation, tectonic deformation and rejuvenated volcanic activity.

\section{Geological Setting}

The MC is a broad triangular seaway located between the Madagascar continental slope to the east and the Mozambique continental slope to the west (Fig. 1A). Its formation resulted from the break-up of the western (South America and Africa) and eastern (Madagascar, India and Australia) Gondwana in the Middle Jurassic (e.g. Gaina et al., 2013). This rifting period was accompanied by the relative motion of Madagascar with respect to Africa ( 165-120 Ma) through a major transform fault presently illustrated by a $1200 \mathrm{~km}$ long bathymetric high called the Davie Ridge (DR, e.g. Bassias, 1992; Coffin and Rabinowitz, 1987, Fig. 1A). During the Late Cretaceous, an important onshore (e.g. Storey et al., 1995; Torsvik et al., 2000) but also, potentially, offshore volcanic activity north of Madagascar (Courgeon et al., 2016b) occurred coevally with the activity of the Marion hotspot and the Madagascar-India break-up. During the Late Cenozoic, the MC recorded renewed geodynamic activity expressed by volcanism in the Comores archipelago (Michon et al., 2016) and in southern MC (Courgeon et al., 2016b), as well as extensional tectonic deformation along the Davie Ridge (Courgeon et al., 2016b). Timing, location and nature of 
these tectonic episodes suggest that they are linked to the development and the propagation of the East African rift system (Salman and Abdula, 1995; Chorowicz, 2005; Kusky et al., 2010; Franke et al., 2015; McGregor, 2015; Stamps et al., 2015; Courgeon et al., 2016b; Michon et al., 2016).

Nowadays, the MC hosts several isolated carbonate platforms called the "Iles Eparses" (Fig. 1B). These carbonate platforms are characterized by typical shallow-water tropical carbonate production dominated by corals, benthic foraminifera, green algae and mollusks (Battistini, 1976; Jorry et al., 2016; Prat et al., 2016). The Iles Eparses isolated carbonate platforms are characterized by asymmetrical geomorphologies driven by dominant winds, and evolve under different hydrodynamic settings. They are typified by the occurrence of exposed fossil reefs from the Last Interglacial (Guillaume et al., 2013; Jorry et al., 2016). On the Glorieuses Archipelago, the flanks of carbonate platforms exhibit successive submerged terraces that are interpreted as resulting from reef growth during the last deglacial sea-level rise (Jorry et al., 2016).

The south central part of the MC is characterized by a $100 \mathrm{~km}-$ long seamount chain consisting of two guyots, the Hall and Jaguar banks, and of the modern atoll of Bassas da India fringed by a $12 \mathrm{~km}$ wide submarine terrace (Fig. 1B).The submerged flat-top edifices, lying at hundreds of meters water depth (-800 to $-120 \mathrm{~m})$, correspond to drowned Neogene shallow-water carbonate platforms that probably colonized volcanic reliefs during Early Miocene time (Courgeon et al., 2016b). These carbonate platforms, characterized by successive terrace levels, are cut by well-developed normal faults (Fig. 1B) and their tops are extensively covered by volcanic material and morphologies. However, the architecture of these carbonate platforms is unknown and the nature and the timing of tectonic and volcanic processes interacting with carbonate platform development remain obscure. Moreover, the Jaguar Bank is still undated and no model has been proposed to explain differential evolutions 
and final growth of Bassas da India modern atoll. This area represents a first order target to study the impact of tectonic and volcanic activities on the long-term evolution of carbonate platforms as a consequence of the isolated nature of these carbonate platforms and the diversity of their modern architectures (i.e. drowned carbonate platforms vs. modern atoll).

\section{Material and methods}

This work is mainly based on geophysical and geological data acquired during the 2014 PTOLEMEE (Jorry, 2014) and PAMELA-MOZ1 (Olu, 2014) cruises onboard the RV L'Atalante and during the 2015 PAMELA-MOZ4 (Jouet and Deville, 2015) cruise on board the RV Pourquoi pas? Geological interpretations presented in this study result from the combined analysis of (1) multi-resolution seismic profiles, (2) bathymetry DEMs and associated slope maps, (3) dredged rock samples, and (4) underwater videos.

The seismic dataset was collected using the seismic acquisition system SEAL (Sercel, Ifremer). "Fast seismic" (CRUISE-SRxxx) data were acquired using a 24 traces and 600m streamer with a $12.5 \mathrm{~m}$ inter-trace interval (10 knots speed). Fast seismic processing consists of stacking and migration at constant velocity. For high-resolution seismic (CRUISE-HRxxx), data were acquired using 72 traces and $930 \mathrm{~m}$ streamer with a 6.25 inter-trace interval (5 knots speed). For HR seismic, processing was conducted, when possible, using velocity analysis. Locally, seismic data used in this study suffers from low penetration and disturbed signal induced by direct contact on the seafloor between seawater and rocky seabed. Seismic interpretations have been conducted using coupled analysis of both, HR seismic and fast seismic (lower resolution), datasets.

Bathymetric data were acquired with Kongsberg EM122 and Kongsberg EM 710 multibeam systems. Data were processed using CARAIBES $^{\mathrm{TM}}$ v4.2 software and were gridded into 20, 10 and 5m resolution DEMs (WGS84). Geomorphological and morphometric 
analysis were carried out with $\operatorname{ArcGIS}^{\mathrm{TM}}$ v10.3 using customized Mercator projections. Underwater videos and pictures were conducted with the SCAMPI camera system (IFREMER) and were used to better constrain submarine geomorphologies.

Rock samples were collected using rock (CRUISE-DRxx-sample), Niwa (CRUISEDNxx-sample) and Warren (CRUISE-DWxx-sample) dredges. The petrographic analysis combines hand sample and thin section observations. The interpretation of carbonate depositional environments relies on biological assemblages and depositional textures and was supplemented by a diagenetic study to evidence reworking, alteration and potential periods of subaerial exposure. Stratigraphic data are based on: (1) planktonic and benthic foraminifera biostratigraphy (BouDagher-Fadel, 2008, 2013, 2015), and (2) strontium isotopic stratigraphy (SIS; McArthur, 2012). (Details on dating methods are given in Courgeon et al. (2016b).Younger carbonate samples have been dated by radiocarbon technique.

\section{Results and interpretations}

\subsection{Geophysical analysis}

\subsubsection{Seismic stratigraphy}

Seismic profiles carried out along the Hall Bank, the Jaguar Bank and Bassas da India terrace (Fig. 2, $3 \& 4$ ) are characterized by two major seismic facies (SF1 and SF2) and by a minor one (SF3) which is restricted to Bassas da India. Both low resolution (Fig. 2) and high resolution (Fig. 3\&4) seismic datasets are typified by these three seismic facies. The first seismic facies (SF1) is mostly characterized by low to moderate amplitudes, semi-continuous to discontinuous reflections and by chaotic to wavy internal configurations (Fig. 2, $3 \& 4$ ). Locally, SF1 is marked by horizontal and oblique, more continuous reflections that display aggrading (e.g. Fig. 2A) and prograding (e.g. Fig. 2B) patterns. This seismic facies, which 
prevails in studied profiles, is rapidly mitigated in depth where seismic reflections are lost and locally replaced by homogeneous chaotic facies sometimes marked by sub-horizontal blurry horizons that most likely correspond to seismic artifacts (e.g. Fig. 2A).While SF1 apparent thickness is sometimes very low, as for instance along high-resolution seismic profiles (Fig. 2A), it can reach up to $200 \mathrm{~ms}$ on fast seismic dataset (Fig. 2C).The second seismic facies (SF2) is characterized by moderate to high amplitude, semi-continuous to discontinuous reflections (Fig. 2, $3 \& 4$ ). It is typified by various geometries including, horizontal, oblique and chaotic reflections. SF2 is observed in the most superficial part of the seismic profiles and seemingly covers deeper SF1 reflections (Fig. 2, $3 \& 4$ ). Along some platform edges (Fig. 2A \& 2B), SF2 high-amplitude and oblique reflections form seaward prograding wedges. Vertical SF2 thickness ranges from less than $10 \mathrm{~ms}$ up to $200 \mathrm{~ms}$ (Fig. 2A \& 3A). The third seismic facies (SF3) is only observed at Bassas da India (Fig. 2C \& 4). It is characterized by continuous to chaotic reflections of low to moderate amplitudes. Overall, SF3 seems to cover and fill reliefs formed by SF1 and SF2, however, high amplitude reflections and continuous SF2 reflections are locally interbedded (Fig. 4). Finally, the top of Bassas da India main terrace (Approx -500m deep, Fig. 1B) is partly covered by undulating geometries up to $20 \mathrm{~ms}$ high that are associated to SF3 (Fig. 2C \&4).

SF1 and SF2 are separated by an irregular seismic unconformity, U1 (Fig. 2, 3 \& 4). While sometimes $\mathrm{U} 1$ is marked by a relatively continuous peak (Fig. 2B, 2C, 3C\& 3D), it is also frequently only typified by reflection terminations and/or seismic facies change (e.g. Fig. 2A, 2C, 3A \& 3B). U1 is mainly marked by onlaps of SF2 reflections (Fig. 2A, 2C, 3A\& 3B) but is also characterized by toplaps (Fig. 3C), downlaps (Fig. 3B) or concordance (Fig. 3D). $\mathrm{U} 1$ is typified by a very rugged topography locally related to the occurrence of welldeveloped depressions (Fig. 2, 3 \& 4), 100m to $1500 \mathrm{~m}$ wide and up to $200 \mathrm{~ms}$ in depth (e.g. Fig. 2A \& 3A). They are mostly filled by high-amplitude onlapping SF2 reflections but also 
exhibit complex geometries marked by downlaps. On top of the Hall Bank, a large depression is not entirely filled and forms a flat-bottom negative topography along the seafloor (Fig. 2A). Moreover, the base of this depression is not observed on seismic profiles. At Bassas da India, the large conic depression is typified at its base by a complex reflections configuration that also suggests that U1 is not continuous (Fig.4). However, on fast seismic, U1 appears continuous along the equivalent depression (Fig. 2C), probably due to the lower seismic resolution. This depression is marked at its bottom by high amplitude SF2 reflections but is also filled by SF3 reflections (Fig. 2C \&4). Furthermore, the seafloor is characterized by SF2 reflection toplaps indicating post-deposition erosion (e.g. Fig. 2A, 3A \& 3D).

\subsubsection{Surface geomorphology and seismic interpretations}

Drowned carbonate platforms from the southern MC are partly covered by rugged and positive morphologies that present typical texture of submarine lava flows (Fig. 5; McClinton and White., 2015; Courgeon et al., 2016b). On the Jaguar Bank (Fig. 5B), the smooth surface of the drowned carbonate platform is covered by fingered and flowing features interpreted as lobate lava flows (Fig. 6A; see Gregg and Finck, 1995). These systems exhibit well preserved lava channel and levee morphologies (Fig. 6A). Underwater pictures of these morphologies confirm the occurrence of a direct contact between rough and dark volcanic rocks (Fig 6C \& 6D), marked by typical polygonal fracturing network (see Yamagishi, 1991), and bright and flat carbonate slabs (Fig. 6B). Volcanic reliefs locally show elongate channel-shaped depressions (Fig. 5B) that seemingly correspond to lava channels and/or tubes (e.g. Fornari, 1986). On the Hall Bank, volcanic morphologies that seemingly entirely cover carbonate platform, present low reliefs, domed and very rugged morphologies (Fig. 5A) similar to inflated lava lobes (see Deschamps et al., 2014). 
The seafloor geomorphology on southern MC flat-top seamounts suggests therefore that SF1 corresponds to carbonate platform deposits and that SF2 corresponds to volcanic material. SF1 is typified by overall low amplitude, chaotic to wavy reflections (Fig. $2,3 \& 4$ ) and exhibits typical characteristics of shallow-water carbonate platform deposits (e.g. Bachtel et al., 2004; Burgess et al., 2013). Overlying SF1, SF2 is characterized by higher amplitudes and locally parallel reflections (Fig. $2,3 \& 4$ ) that correspond to volcanic deposits and lava flows observed at the top of drowned carbonate platforms (Fig. $5 \&$ 6). High-amplitude reflections that form prograding wedges along platform margins display striking similarities with lava deltas (e.g. Wright et al., 2012).

The U1 seismic unconformity is thus interpreted as the contact between volcanic material and underlying carbonate deposits. Topographic irregularities and depressions observed along U1 (Fig. 2, $3 \& 4$ ) could correspond to karstic features, thus implying the occurrence of extended periods of subaerial exposure. These depressions, filled by volcanic material, are locally associated to SF1 erosional reflection terminations (Fig. 3A \& 4A) also suggesting a post-depositional origin. Undulating geometries observed along the Bassas da India seismic profile (Fig. 2C \&4) are associated to thin and elongate positive morphologies (Fig. 5C) interpreted as sand ridges and gullies system partly covering volcanic reliefs. The nature of SF3 reflections remain unclear, and may correspond to carbonate sediments, volcanic material or mixed deposits.

The top of the Hall Bank is typified by a 1300m wide, circular and flat-bottom depression which is $40 \mathrm{~m}$ deep compared to the surrounding sea-floor (Fig. 5A \&7A). This depression appears discontinuous in subsurface, forming a partially filled conic feature whose base could not be observed (Fig. 2A). On the seafloor, its bottom is characterized by a central pit and by concentric positive ridges (Fig. 7A) associated to very dark volcanic material (Fig. 7D) and interpreted as volcanic "ring" dykes. These observations suggest that this depression 
results from volcanic activity (explosive ?). The large and conic depression observed on Bassas da India southern terrace (Fig. $2 \mathrm{C} \& 4$ ) might also be volcanic in origin. Smaller, rounded and closed to semi-enclosed shallow depressions observed along volcanic reliefs on top of the Hall Bank (Fig. 5A) would probably more result from collapsing events associated to deposition and cooling of volcanic material (e.g. Halliday, 2007; Chadwick et al.,2013). Finally, the summits of flat-top seamounts are typified by extensive pebble fields (Fig. 7B \& 7C) suggesting the occurrence of erosional events after volcanic production, in agreement with seismic data set (SF2 toplaps).

The summit of the Jaguar Bank (Southern extremity, Fig. 8A) is marked by a rounded, overall flat and smooth morphology sited on faulted and rugged antecedent volcanic reliefs. This $2 \mathrm{~km}$-wide morphological feature displays typical characters of a carbonate build-up and occurs down to $117 \mathrm{~m}$ deep. Along the southern flank of Bassas da India, the large drowned carbonate platform covered by volcanic products and bounded by major normal faults, exhibits successive rounded and flat-top morphologies interpreted as subsequent carbonate terraces (Fig. 5C; Courgeon et al., 2016b), which typify the evolution of the carbonate system toward its modern atoll morphology.

\subsubsection{Structural analysis}

The southern MC seamounts are affected by a dense normal fault network structuring the drowned carbonate platforms into various structural blocks (Fig. 1, 2, 4, 5,6 \& 8; Courgeon et al., 2016b). The different platforms are not affected by faulting in a similar way. At the Jaguar Bank, extensional deformation is responsible for tilted panel and horst and graben structures (Fig. 1, 2A, 5B \& 8) with vertical offset up to $100 \mathrm{~ms}$ along seismic profiles. At Bassas da India, faulting induced successive collapsed structures along its southern flanks (Fig. 1, 2C, $4 \& 5 \mathrm{C}$ ). The large terrace is bounded by two prominent faults escarpments (up to 
200m, Fig. 5C) that most likely form a single major fault responsible for the downward shift of this block along Bassas da India southern flank. At the opposite, the Hall Bank is only typified by rare faults(Fig. 1) that do not seem to affect its structure. Northeastwards of the volcanic ridge, basinal sedimentary layers are marked by well-developed normal faults that frequently reach the seafloor (Fig. 9A).These normal faults can be joined to the dense network affecting the south MC seamounts and platforms, highlighting a clear SW-NE corridor of extensional tectonic deformation (Fig. 9B).

\subsection{Dredged samples analysis}

Dredged samples used in this study can be divided into two subgroups: (1) the rock samples collected along the flanks of the carbonate platforms that reflect their growth and development, and (2) rock samples collected on top of carbonate platforms, which record their demise and subsequent events.

\section{$\underline{\text { 4.2.1. Carbonate platform flanks }}$}

Two rock samples have been recovered on the southwestern flank of the Hall Bank (DR18, see location on Fig. 1B): MOZ1-DR18-01 and MOZ1-DR18-02. MOZ1-DR18-01 corresponds to a skeletal packstone typified by large, of several millimeters in size, corals fragments often encrusted by red algae and encrusting foraminifera. MOZ1-DR18-01 also includes abundant LBF (e.g. Cycloclypeus sp.; Fig. 10A) and is Burdigalian in age (Tab. 1), as indicated both by SIS (16.29+/- 0.10 Ma) and foraminifera biostratigraphy (N8a, 17 - 15.9 Ma). MOZ1-DR18-02 corresponds to a grainstone dominated by LBF (mainly miogypsinids, e.g. Miolepidocyclina exentrica ; Fig. 10B) and bearing abundant Halimeda sp. fragments. SIS and foraminifera assemblages indicate a Langhian age (Tab. 1). A sample collected along the southern flank of the Jaguar Bank (MOZ4-DR05-01, see location on Fig. 1B \& 8A) corresponds to a skeletal packstone also including encrusted large coral grains (Fig. 10C), 
Halimeda sp., LBF (e.g. Operculina sp., Lepidocyclina sp., Sphaerogypsina sp., Fig. 10D) and red algae. Dating indicate that MOZ4-DR05-01 is Serravallian to Tortonian in age (Tab. $1)$.

Two rock samples have been collected along the southeastern flanks of Bassas da India (MOZ1-DR20, see location on Fig. 1B \& 5C). MOZ1-DR20-01(Fig. 10E) corresponds to a skeletal packstone bearing abundant planktonic foraminifera, remains of coral fragments, mollusks (especially gastropods) and, occasionally, volcanic clasts. The occurrence of crystal silts (or vadose silts) in the moldic porosity (Fig. 10F) indicates periods of subaerial exposure (e.g. Dunham, 1969; Flügel, 1982).The foraminifera assemblage described in DR20-01 does not provide a clear indication of its age (i.e. Miocene - Pliocene, Tab. 1), but SIS gives a Tortonian age (8.48 +/- 0.49 Ma). MOZ1-DR20-01 is also typified by reworked Miogypsina LBF that are characteristic of the Early to Middle Miocene (BouDagher-Fadel, 2013b).The second rock sample collected along the southeastern flank of Bassas da India (MOZ1-DR2002, Fig. 10G) corresponds to a skeletal packstone dated of the Messinian by both SIS and biostratigraphy (Tab. 1).

Rock samples collected along carbonate platforms flanks comprise biological assemblages that are dominated by corals, LBF, red algae and green (Halimeda) algae and typically reflect photo-autotrophic carbonate production system of tropical shallow-water factory (e.g. "T factory"; Schlager, 2003). LBF frequently present robust forms (e.g. Fig. 10B \& 10D) indicating high-energy environments (e.g. Hallock and Glenn, 1986, Jorry et al., 2003; Beavington-Penney and Racey, 2004).The abundance of large hermatypic coral fragments coated by red algae and encrusting foraminifera (e.g. Fig. 11A, 11C\& 11G) as well as widespread Halimeda (Tab. 1) could suggest the occurrence of reef buildups (e.g. Flügel., 1988; Reuter et al., 2012). Finally, stratigraphic results combining SIS and foraminifera 
biostratigraphy show that these isolated and shallow-water carbonate platforms develop during Miocene times (Tab. 1).

\subsubsection{Carbonate platform tops}

In the northeastern part of the top of the Hall Bank (MOZ1-DW05; see location on Fig. 1B \& 5A), diverse volcanic and carbonate pebbles have been collected (Fig. 7B). They are frequently coated by thin $(<10 \mathrm{~mm})$ Fe-Mn dark crusts (Fig. 7C, Courgeon et al., 2016b). MOZ1-DW05-C1 corresponds to a dolomitized, coral-rich and perforated limestone reworked into a packstone of planktonic foraminifera (Fig. 11A).While the dolomitized limestone could not be dated, the enclosing packstone is Early Pliocene in age, as indicated by SIS and foraminifera biostratigraphy (Tab. 1). MOZ1-DW05-C2 consists of a planktonic foraminifera packstone included into a dark tuff including heterogeneous mineral and carbonate fragments (Fig. 11B). The packstone is Pleistocene in age, as indicated by SIS and biostratigraphy (Tab. 1). It includes dark volcanic clasts and is typified by a network of laminated bright crusts that correspond to phosphatization features. Finally, MOZ1-DW05-10 mainly consists of heterogeneous, vesicular, bright and angular fragments that correspond to coarse ashes and lapilli (Fig. 11E). Some volcanic clasts are fringed by thin $(<0.1 \mathrm{~mm})$ dark layers (Fig. 11E) and are interpreted as armored lapilli. These volcaniclasts typically characterize violent volcanic eruptions implying contact between surface or shallow phreatic waters and magma (e.g. Houghton et al., 2015). In parallel, this volcanic tuff consists of brownish and rounded carbonate clasts including skeletal grains (e.g. red algae, Fig. 11E).

Heterogeneous limestone samples were collected in the western area of the Jaguar Bank (MOZ4-DN02-02, See location on Fig. 1B \& 5B). MOZ4-DN02-02c (Fig. 11D) corresponds to dolomitized grainstone reworked into a planktonic foraminifera wackestone. The grainstone comprises abundant red algae, Halimeda sp., corals and LBF and is 
characterized by Miogypsina indicating an Early to Middle Miocene age (BouDagher-Fadel and Price, 2013b); the wackestone infills porosity and is Pliocene in age (Tab. 1). MOZ4DN02-02d (Fig. 11C) corresponds to a phosphatized skeletal packstone dominated by Pliocene planktonic foraminifera and including large coral and algal fragments.

A massive piece of altered olivine nephelinite (MOZ4-DR08) has been collected along the southern terrace of Bassas da India (see location on Fig. 1B \& 7C) and corresponds to a bloc of lobate lava flow (Fig. 11F).The associated network of fractures is filled first by a wackestone rich in planktonic foraminifera (MOZ4-DR08-01b, Fig. 11F) dated of the Early Pliocene (Tab. 1). This first infilling is intersected by fractures filled by a phosphatized planktonic foraminifera packstone typified by numerous Halimeda plates and red algal fragments (MOZ4-DR08-01a, Fig. 11G). Although differences in age are observed between SIS and biostratigraphy (400 kyr gap between SIS and biozone younger boundary, Tab.1), they both suggest that MOZ4-DR08_02a is Pleistocene in age.

Overall, limestone samples collected along drowned carbonate platforms tops correspond to Pliocene-Pleistocene wackestones and packstones bearing planktonic foraminifera. These limestones are characteristic of outer shelf environments and commonly include reworked and altered shallow-water carbonate assemblages similar in composition (e.g. LBF, corals, red algae) and age (i.e. Miocene) to rock samples collected along carbonate platform flanks (Fig. 10). They were deposited after the cessation of Miocene shallow-water carbonate platform development. Limestone recovered on tops of carbonate platforms are moreover typified by encrusting Fe-Mn mineralization (Fig. 7C, Courgeon et al., 2016b) and widespread phosphatization figures (Fig. 11B, 11C \& 11G). These features are characteristic of hardgrounds that typically develop during long periods of non deposition within marine environment (e.g. Murdmaa et al., 1995; Mangini et al., 1987; Camoin et al., 1998). Reworked assemblages are otherwise locally marked by extensive dolomitization (Fig. 11A \& 
11D).In parallel, dredging on tops of seamounts have also collected various volcanic samples, which characterize both explosive (i.e. Tuff,, Fig 11B \& 11E) and effusive (i.e. lava, Fig. 11F) activity.

Finally, the carbonate build-up which is located at the top of the Hall bank (MOZ4DR06, see location in Fig. 1B \& 8A) is comprised of well-preserved limestones including coral boundstone and Halimeda sp. grainstones (Fig. 8B). ${ }_{14} \mathrm{C}$ dates obtained on coral and Halimeda sp. gave ages ranging from 13.7 to $11.2 \mathrm{ka} \mathrm{Cal} \mathrm{BP}$ and from 10.9 to $10.6 \mathrm{ka} \mathrm{Cal} \mathrm{BP}$ respectively (Latest Pleistocene - Holocene)

\section{Discussion}

\subsection{Onset, growth and demise of Miocene shallow-water carbonate platforms}

The oceanic volcano(es) that formed the substratum of southern MC carbonate platforms were most probably subaerially exposed before being weathered and eroded, especially through wave activity, and colonized by shallow-water carbonate producers (Fig. 12).This development pattern is broadly accepted to explain the accretion of isolated carbonate platforms on volcanic seamounts and, ultimately, the formation of guyots (e.g. Camoin et al., 1998; Staudiguel and Clague, 2010). The distinctive general morphologies of the southern MC carbonate platforms, especially their size and shape (Fig. 1B) are thus probably inherited from the geometry of the underlying volcanic units (Fig. 12). While seismic data indicate the occurrence of thick carbonate sedimentary layers (up to $200 \mathrm{~ms}$ TWT, Bassas da India, Fig. 2C), the contact between the volcanic substrate and the overlying carbonates was not directly observed nor sampled. The oldest shallow-water carbonates which were recovered in the study area are Burdigalian in age (MOZ1-DR18-01, Tab.1) and therefore suggest that the final stage of volcano(es) edification as well as the onset of shallow- 
water carbonate sedimentation probably occurred not later than Late Oligocene to Early Miocene times (Fig. 12).

Drowned carbonate platforms of the southern MC are characterized nowadays by a complex structure comprised of successive terraces (Fig. 1, 2, $5 \& 8$ ), that are inherited from development and backstepping phases of isolated carbonate platforms, as well as from structural deformation (Courgeon et al., 2016a). The biological assemblages that typify the southern MC Miocene platform carbonates (Fig. 10) are dominated by corals, red algae and LBF (Tab. 1). This composition is consistent with global trend in tropical carbonate production during the Neogene (Pomar and Hallock, 2008). Carbonate production on the southern MC isolated carbonate platforms was also characterized by the abundance of Halimeda green algae (e.g. Fig. 10B \& 10D) which may have formed buildups as it was reported in Late Miocene carbonate systems from the Mediterranean (e.g. Braga et al., 1996; Bosellini et al, 2001). Similar bilogical assemblages have been commonly described in Miocene shallow-water carbonate systems from the Indo-Pacific realm (e.g.Queensland Plateau: Betzler and Chaproniere, 1993; Sarawak: Mihaljevic et al., 2014; Sulawesi: BouDagher-Fadel., 2002; South China Sea: Sattler et al., 2004). Our sedimentological results, coupled with geomorphological and seismic data, suggest that the southern MC Miocene carbonate systems were flat-topped and shallow-water open platforms (e.g. sensu Pomar et al., 2012) hosting, at least temporarily, reef complexes. In the absence of clear rim morphologies along seismic profiles (Fig. 2), the occurrence of isolated bioherms and patch reefs is privileged over that of typical barrier reefs. The occurrence of well-developed prograding morphologies (SF1, Fig. 2B) on the northern margin of the Jaguar Bank suggests an asymmetric development of the carbonate platform that could be related to prevailing southern winds, as observed nowadays on Europa (Jorry et al., 2016). The evolution of biological assemblages in the southern MC platform carbonates during the Miocene (e.g. 
relative abundance of Halimeda vs. LBF, Tab. 1) could reflect changes in carbonate platform geometry and production type, which could have been triggered by major climatic fluctuations that have been already reported in other areas (e.g. Brachert et al., 1996; Betzler et al., 2012). However, a detailed depositional model cannot be reconstructed accurately due to the relative scarcity of dredged samples collected on these carbonate platforms (Fig. 1B) as well as their large stratigraphic distribution (Tab.1). Drowned Miocene carbonate platforms are characterized by well-developed karstic topographies (e.g. depressions, Fig. $2 \& 3$ ) and freshwater diagenetic features (e.g. vadose silts, Fig. 10F), which suggest extended periods of subaerial exposure during their development. Many Mesozoic isolated carbonate platforms from the Pacific realm also recorded dissolution and erosion processes in subaerial environments during their evolution (e.g. Van Waasbergen and Winterer, 1993; Camoin et al., 1998).

The stratigraphic and sedimentologic data obtained on carbonate samples collected along the flanks and at the tops of flat-top seamounts (Fig. 10 \& 11, Tab. 1) suggest that the end of shallow-water carbonate sedimentation and the drowning of the carbonate platforms occurred during the Middle Miocene - Early Pliocene time span (Fig. 12). The youngest carbonate deposits exhibit typical hardground features (e.g. borings, Fig. 10A; phosphatization, Fig. 11B \& 11C), which characterize drowning unconformities in carbonate depositional sequences (e.g. Schlager, 1989; Camoin et al., 1998; Godet, 2013). On Cretaceous Pacific guyots, such drowning unconformities are capped by shallow-water carbonate deposits that are frequently covered by convex upward pelagic caps (e.g. Van Waasbergen and Winterer, 1993; Camoin et al., 1998; Wilson et al., 1998). In the Southern MC, the sedimentary package that caps the drowned carbonate platforms do not display distinctive morphologies and its content in pelagic sediments is seemingly very restricted in contrast to abundant reworked shallow-water carbonate grains (Fig. 11). This could be related 
to the relative young age of the southern MC guyots and/or by strong current activity at their summit which could have prevented a significant accumulation of pelagic sediments.

\subsection{Nature and timing of rejuvenated volcanism and tectonic deformation}

Drowned and karstified Miocene carbonate platforms are laterally extensively covered by submarine lava flows (e.g. lobate lava flow, inflated lava lobes; Fig. 12) (e.g. Fig. 2, 5, 6 \& 8; Courgeon et al., 2016b), which indicate the occurrence of a volcanic activity after the cessation of carbonate platform development. On Bassas da India, the dating of carbonates filling fractures affecting lava blocks (Fig. 11F \& 11G; Tab. 1) indicates that volcanic eruptions occurred during, or relatively shortly before, the Early Pliocene and was therefore overall coeval to the drowning of the carbonate platform. Although no clear volcanic features intersecting platform carbonate were documented on seismic profiles, probably due to the resolution of seismic images, the magmatic material most likely reached the surface through fractures networks (Fig. 12). As described on other carbonate platforms (e.g. FernandezMendiola and Garcia-Mondejar, 2003), faults and associated weaker zones may also potentially act as pathways for magmatic intrusion during volcanic events. Moreover, drowned carbonate platforms include volcaniclastic deposits (Fig. 11B \& 11E) typified by armored lapilli and carbonate fragments that indicate the occurrence of shallow to subaerial phreatomagmatic explosions within a pre-existing carbonate platform (Fig. 12). These intense eruptions were most likely responsible for the formation of conic diatremes (Fig. 2A \& 4) and rounded and flat-bottom craters (Fig. 5A \&7A) displaying geometric characters which support the hydromagmatic nature of the explosive volcanism (e.g. Maars-diatreme volcanoes, White and Ross, 2011). Volcanic-related collapsing processes (e.g. caldera, Cole et al., 2005) may also be involved in the formation of these deep depressions into the carbonate platform(s). The occurrence of ring dykes at the bottom of the Hall Bank crater morphology (Fig. 7A) might suggest post-eruptive magmatic injections through passive fracture systems or lava lake 
collapse. Furthermore, the abundance of volcaniclastic pebbles (Fig. 7B) suggests episodic subaerial exposures that were responsible for the reworking of volcanic material. Similar volcaniclastic deposits, associated with phreatomagmatic eruptions through carbonate platforms, have been reported in the depositional sequence of the Oman Triassic carbonate platform (Basile and Chauvet, 2009) and on the Early Cretaceous MIT Guyot in the Western Pacific (Martin et al., 2004). Finally, volcaniclastic deposits collected on top of the Hall Bank locally include Pleistocene carbonate fragments that indicate recent explosive volcanic activity in this region (Fig. 11B \& 12; Tab. 1), in agreement with the occurrence of a very well preserved crater morphology (Fig. 7A).

The southern MC drowned carbonate platforms were affected by major extensional tectonic deformations creating a complex network of high-offsets normal faults, which dissected the seamounts into numerous and distinctive structural blocks (Fig. 12). These faults belong to a SW-NE corridor of tectonic deformation (Fig. 9B) that probably extends regionally and that could be linked to the development and the southern propagation of the East African Rift System during the Neogene (Stamps et al., 2005; Courgeon et al., 2016b). Although the spatial relationships are complex, the network of normal faults frequently intersects lava flows (e.g.. Jaguar Bank, Fig. 5B), suggesting that tectonic deformation persisted after effusive volcanic activity (Fig. 12). This tectonic deformation was associated with huge (up to $200 \mathrm{~m}$ high, Fig. 5) vertical movements involving very important subsidence rates along collapsed and tilted blocks (Fig. 12). Furthermore, normal faults affect basinal sediments around the seamounts and usually reach the sea floor (Fig. 9A), thus indicating that the tectonic movements have persisted until very recent to modern times. High-amplitude vertical motions and dense faulting observed along studied seamounts might also be partly caused by gravity collapse related to volcanism (e.g. Staudiguel and Clague, 2010). 


\subsection{The renewal of shallow-water carbonate production and the edification of modern}

atoll

During the Late Neogene, shallow-water carbonate producers colonized a horst structure and form a rounded and small $(<2 \mathrm{~km}$ wide $)$ carbonate build-up that presently occurs at $117 \mathrm{~m}$ water depth at the top of the Jaguar Bank (Fig. 8A\& 12). Dating results obtained on coral buildups and Halimeda grainstones collected at the top of this bank (Fig. 8B) suggest a drowning event during a latest Pleistocene - early Holocene time window (13-8 ka), probably due to an abrupt increase in accommodation induced by the last deglacial sea-level rise (e.g. Clark et al., 2009). Along the southern flank of Bassas da India, several terrace morphologies are located on volcanic reliefs capping drowned Miocene carbonate platforms (Fig. 5C). The first terrace occurs at $250 \mathrm{~m}$ water depth and is interpreted as a part of a Late PliocenePleistocene carbonate platform that collapsed along a major normal fault with the southern flank of Bassas da India (Fig. 12). The Pleistocene carbonate deposits bearing abundant shallow-water skeletal components (MOZ4-DR08-01a, Fig. 11G; Tab. 1), which fill fractures in lava blocks collected on top of a Miocene drowned carbonate terrace, could correspond to sediments that were transported from this carbonate platform. The flat-top terrace that is observed at 120m deep (Fig. 5C\& 12A) could correspond to a Pleistocene carbonate terrace resulting from backstepping processes during atoll growth (see Webster et al., 2009). However, this morphological feature could correspond to an erosional notch induced by wave action or to small reef developing along platform slope during the Last Glacial Maximum lowstand (e.g. Camoin et al., 2001) which is usually reported at about $120 \mathrm{~m}$ water depth (see Clark et al., 2009 and references herein). In the end, the latest phases of carbonates development, which have driven the edification of the Bassas da India atoll, were seemingly limited to topographic highs inherited from tectonic deformations (Fig. 12).While Darwin's subsidence-driven model (1842) has been widely accepted to explain the origin of the bucket 
morphology of modern atolls, more recent studies have demonstrated that the origin of these sedimentary edifices may be rather related to: (1) the biotic self-organization of reef builders (Schlager and Purkis, 2013) and, (2) high amplitude sea-level fluctuations that involved alternate phases of reef growth along atoll rim during highstands and dissolution of lagoonal sediments during lowstands (e.g. Toomey et al., 2016). It seems likely that the occurrence of the Bassas da India modern atoll is also associated to topographic features that are inherited from the previous development of the underlying carbonate platform and reefs, such as the Pliocene-Pleistocene carbonate platform which potentially forms its substrate (Fig. 12).The southern carbonate terraces of the Bassas da India atoll are partly covered by sandy deposits forming well-developed ridges and gullies (Fig. 2C, 4 \& 5C). These sedimentary bodies are most likely fed by material resulting from erosion and skeletal production of modern reef systems (Fig. 12) and trapped on wide and flat terraces during their transportation towards the adjacent basin.

\subsection{Origin of Miocene carbonate platforms drowning and controls on long-term evolution of carbonate platforms}

Drowning of reefs or shallow-water carbonate platforms occurred when rates of accommodation creation, induced by eustatic rise and/or subsidence, outpace carbonate growth potential (e.g. Schlager et al., 1981; Toomey et al., 2013). Drowning events are frequently associated with the degradation of carbonate factories induced by major changes in environmental and climatic conditions (e.g. Hallock and Schlager, 1986; Camoin et al., 1998; Wilson et al., 1998). South MC drowned carbonate platforms are structured by high-offset normal faults inducing major tectonic subsidence and volcanic morphologies directly overlay shallow-water carbonate platform deposits (fig. 12). Moreover, our result indicate that at Bassas da India, eruptive activity was coeval with the end of shallow-water carbonate sedimentation, i.e. during Late Miocene-Early Pliocene (Tab. 1). We hence propose that 
drowning of south MC Miocene shallow-water carbonate platforms was primarily triggered by the combination of (1) the extensive coverage of shallow-water carbonates and the smothering of involved biological communities by volcanic material (i.e. lava flows and volcaniclastics), (2) the degradation of environmental conditions (e.g. water turbidity and chemistry) induced by volcanic eruptions and associated inputs, and (3) a sharp increase in accommodation induced by extensional tectonic deformation and related subsidence. While our geomorphological analysis demonstrates that the latest effusive volcanic flows took place in a marine environment (e.g. lobate lava flow, Fig. 6) where they sealed the drowning of the carbonate platform, previous eruptions might have occurred in a subaerial environment or at very shallow depth. Inputs of volcanic ash particles, very rich in various elements (e.g. Fe, $\mathrm{Si}$ ), increased water turbidity but also potentially provoked bloom in phytoplankton and surface-water productivity (e.g. Uematsu et al., 2004; Langmann et al., 2010). This effect, that can affect surroundings waters over very wide distance (regional scale), might sustainably deteriorated reef-builders (e.g. corals) development by promoting heterotrophic benthic organism that adapt faster to high nutrients contents (e.g. macroalgae or cynaobacteria, Houk, 2011) and reduced light penetration. Finally, the release gas induced by volcanic activity (e.g. $\mathrm{CO} 2$ ) could also dramatically disrupted the development of Miocene shallow-water benthic carbonate producers (e.g. Hall and Spencer, 2008).

Our chronostratigraphic results reveal an apparent SW-NE gradient between the Hall Bank and Bassas da India where Burdigalian-Langhian and Tortonian-Messinian limestones have been recovered respectively, through the Jaguar Bank which is characterized by Serravallian carbonates (Tab. 1, Fig. 12). This trend suggests diachronous development and drowning phases that could be linked to different and/or diachronous tectonic (e.g. subsidence rates) and volcanic activities on the three carbonate platforms. During the Late Neogene, the shallow-water carbonate production restarted along topographic highs that were produced by 
tectonic movements and/or volcanic accretion (Fig. 8A \& 12). While at Bassas da India, the modern atoll is seemingly located on the footwall of a major normal fault, the ultimate carbonate build-up settled along a narrow horst on the Jaguar Bank (Fig. 12). The absence of renewed shallow-water carbonate production at the Hall Bank (Fig. 12) can be tentatively explained by the lack of tectonically-induced topographic highs and/or by a sustained volcanic activity (e.g. explosive eruptions, Fig. 12) inhibiting shallow-water carbonate production (see Wilson, 2000).

Major impacts of tectonic and volcanic activity have been commonly described on carbonate platforms which develop in active geodynamical settings (e.g. Wilson et al., 2000; Wilson and Lokier., 2002; Menier et al., 2014; Wu et al., 2014; Courgeon et al., 2016a; Paumard et al., 2016). As proposed in this paper, the drowning episodes are usually thought to be triggered by high subsidence rates (e.g. Wu et al., 2014), or by environmental degradation induced by volcanic activity (e.g. Wilson, 2000). The development of carbonate platforms or builds-ups on antecedent fault-bounded and uplifted highs is also very frequent in active tectonic domains (e.g. Lü et al., 2013). Conversely, no significant tectonic and late volcanic activity have been reported during the development, especially during the Neogene, of midoceanic drowned carbonate platforms (e.g. Pacific Guyots: Van Waasbergen and Winterer, 1993; Camoin et al., 1998) and atolls (e.g. Maldives: Belpolsky and Droxler, 2004; Midway atoll: Lincoln and Schlanger, 1987) from the Indo-Pacific realm. The southern MC seamounts represent therefore valuable features to illustrate and assess the impact of tectonic and volcanic activity on long-term evolution of isolated shallow-water carbonate platforms. Otherwise, major Neogene climatic changes (e.g. Zachos et al., 2001) and eustatic fluctuations (e.g. Miller et al., 2005) were frequently considered in drowning episodes affecting the Indo-Pacific isolated carbonate platforms (e.g. Maldives: Betzler et al., 2009; Marion Plateau: Eberli et al., 2010). While long-term south MC carbonate platforms 
evolutions appear in this study mainly controlled by tectonic activity and volcanism, impact of climatic and eustatic changes remain obscure. However, these parameters probably played a significant role in the development of MC Neogene carbonate platforms on shorter time scales, impacting the composition and abundance of biological assemblages (Tab. 1) and the short-term evolution of depositional environments, including periods of subaerial exposure (Fig. 12B).

\section{Conclusion}

The main results of this study can be summarized as follow:

(1) The carbonate platforms from the southern Mozambique Channel developed in shallow-water and tropical settings during the Miocene. They were characterized by biological assemblages dominated by corals, red algae, LBF and Halimeda. These carbonate platforms underwent periods of subaerial exposure that were responsible for the formation of widespread karstic morphologies. Cessation of the shallow-water carbonate production and the drowning of these carbonate platforms occurred during Middle Miocene - Early Pliocene times and was typified by the deposition of outer shelf carbonates bearing hardground features.

(2) From Middle Miocene - Early Pliocene, carbonate platforms underwent rejuvenated activity of their volcanic substratum. Volcanic material directly covered antecedent carbonate platform and filled associated karstic depressions. This volcanism, characterized by both effusive and explosive eruptions, was accompanied by major extensional tectonic deformation that structured the isolated platforms into distinct panels and blocks. These events are seen as the main triggers for Miocene carbonate platforms drowning, especially through rapid tectonic subsidence and environmental degradation induced by volcanic activity. 
(3) During the Late Pliocene and the Pleistocene, shallow-water carbonate production resumed along topographic highs inherited from volcanic accretion and tectonic activity. While carbonate build-ups were locally subsequently drowned, reef growth ultimately led to the edification of the modern atoll at Bassas da India.

The history of the southern Mozambique Channel isolated carbonate platforms represents a new and well-illustrated case highlighting the major impact of tectonic and volcanic activity on the long-term (millions years) evolution of isolated carbonate platforms. However, further investigations, including drilling operations, have to be considered to better assess the evolution of these Neogene carbonate platforms through time, and to discuss the respective impact of environmental and climatic changes, as well as eustatic fluctuations on the Mozambique Channel carbonate platforms development.

\section{Acknowledgments}

We warmly thank Captain, Officers, and crew members of the PTOLEMEE, PAMELA-MOZ1 and PAMELA-MOZ4 (2015, DOI) cruises onboard the R/Vs L'Atalante and the Pourquoi pas? for their technical support in recovering dataset. K. Olu (PAMELAMOZ1 Chief scientist) is acknowledged for Scampi images and videos. The authors are grateful to Philippe Fernagu (Ifremer) for the preparation of thin-sections. The oceanographic expeditions PTOLEMEE, PAMELA-MOZ1, PAMELA-MOZ4 and SC's PhD were co-funded by TOTAL and IFREMER as part of the PAMELA (Passive Margin Exploration Laboratory) scientific project.

\section{References}

Andrieu, S., Brigaud, B., Barbarand, J., Lasseur, E.,, Saucède, T., 2016. Disentangling the control of tectonics, eustasy, trophic conditions and climate on shallow-marine carbonate 
production during the Aalenian-Oxfordian interval: From the western France platform to the western Tethyan domain. Sedimentary Geology 345, 54-84.

Aubert, O., Droxler, A. W., 1992. General Cenozoic evolution of the Maldives carbonate system (equatorial Indian Ocean). Bulletin Des Centres de Recherches ExplorationProduction Elf Aquitaine 16, 113-136.

Bachtel, S.L., Kissling, R.D.,Martono, D., Rahardjanto, S.P., Dunn, P.A., MacDonald, B.A., 2004. Seismic Stratigraphic Evolution of the Miocene-Pliocene Segitiga Platform, East Natuna Sea, Indonesia: The Origin, Growth, and Demise of an Isolated Carbonate Platform, In: G. Eberli, J.L. Massaferro and J.F.R. Sarg (Eds.), Seismic Imaging of Carbonate Reservoirs and Systems. AAPG Memoir 81, 309-328.

Basile, C., Chauvet, F., 2009.Hydromagmatic eruption during the buildup of a Triassic carbonate platform

(Oman Exotics): Eruptive style and associated deformations. Journal of Volcanology and Geothermal Research 183, 84-96.

Bassias, Y., 1992. Petrological and geochemical investigation of rocks from the Davie Fracture Zone (Mozambique Channel) and some tectonic implications.Journal of African Earth Sciences 15, 321-339.

Beavington-Penney, S. J., Racey, A., 2004. Ecology of extant nummulitids and other larger benthic foraminifera: applications in palaeoenvironmental analysis. Earth-Science Reviews 67, 219-265. 
Battistini R., Gayet J., Jouannic C., Labracherie M., Peypouquet J.P., Pujol C., Pujos-Lamy A., Turon J.L. (1976) Etude des sédiments et de la microfaune des îles Glorieuses (Canal du Mozambique). Cah. ORSTOM Ser. Géol. 2, 147-171.

Belopolsky, A.V., Droxler, A.W., 2004. Seismic expressions and interpretations of carbonate sequences: The Maldives carbonate platform, equatorial Indian Ocean.American Association of Petroleum Geologists Studies in Geology49, 46 p.

Betzler, C., Chaproniere, G.C.H., 1993. Paleogene and Neogene larger foraminifers from the Queensland Plateau: biostratigrphy and environmental significance. Proceedinds of Ocean Drilling Programs, Scientific results 133, p 51-66.

Betzler, C., Fürstenau, J., Lüdmann, T., Hübscher, C., Lindhorst, S., Paul, A.,Reijmer., J.J.G.,Droxler, A. W., 2012. Sea-level and ocean-current control on carbonate-platform growth, Maldives, Indian Ocean. Basin Research 25, 172-196.

Betzler, C., Hübscher C., Lindhorst, S., Reijmer, J.J.G., Römer, M., Droxler, A.W., Fürstenau, J., Lüdmann, T., 2009. Monsoon-induced partial carbonate platform drowning (Maldives, Indian Ocean). Geology 39, 867-870

Bosellini, F. R., Russo, A., Vescogni, A., 2001. Messinian reef-building assemblages of the Salento Peninsula (southern Italy): palaeobathymetric and palaeoclimatic significance. Palaeogeography, Palaeoclimatology, Palaeoecology175, 7-26.

BouDagher-Fadel, M. K., 2002.The stratigraphical relationship between planktonic and larger benthic foraminifera in Middle Miocene to Lower Pliocene carbonate facies of Sulawesi, Indonesia. Micropaleontology48, 153-176. 
BouDagher-Fadel, M.K., 2008.Evolution and Geological Significance of Larger Benthic Foraminifera.Developments in Palaeontology and Stratigraphy 21, 1-548.

BouDagher-Fadel, M.K., 2013a.Diagnostic First and Last Occurrences of Mesozoic and Cenozoic Planktonic Foraminifera.Professional Papers Series, 1-4.

BouDagher-Fadel, M.K., Price, G.D., 2013b.The phylogenetic and palaeogeographic evolution of the miogypsinids larger benthic foraminifera.Journal of the Geological Society of London 170, 185-208.

BouDagher-Fadel, M.K., 2015.Biostratigraphic and Geological Significance of Planktonic Foraminifera, London, UCL Press, 298 p.

Brachert, T. C., Betzler, C., Braga, J. C., \&Martin, J. M., 1996. Record of climatic change in neritic carbonates: turnover in biogenic associations and depositional modes (Late Miocene, southern Spain). Geologische Rundschau85, 327-337.

Braga, J. C., Martín, J. M., \& Riding, R., 1996. Internal structure of segment reefs: Halimeda algal mounds in the Mediterranean Miocene. Geology24, 35-38.

Brandano, M., Cornacchia, I., Tomassetti, L., 2017. Global versus regional influence on the carbonate factories of Oligo-Miocene carbonate platforms in the Mediterranean area. Marine and Petroleum Geology, in press

Burgess, P. M., P. Winefield, M. Minzoni, and C. Elders, 2013, Methods for identification of isolated carbonate build-ups from seismic reflection data: AAPG Bulletin97, 1071-1098, doi:10.1306/12051212011. 
Clark, P. U., Dyke, A. S., Shakun, J. D., Carlson, A. E., Clark, J., Wohlfarth, B., Mitrovica, J.X., Hostetler, S.W., McCabe, A. M., 2009. The last glacial maximum. Science325, 710-714.

Camoin, G.F., Arnaud-Vanneau, A., Bergersen, D.D., Enos, P., Ebren, P., 1998. Development and demise of mid-oceanic carbonate platforms, Wodejabato Guyot (NW Pacific).International Association of Sedimentologists Special Publication 25, 39-67.

Camoin, G. F., Ebren, P., Eisenhauer, A., Bard, E., Faure, G., 2001. A 300 000-yr coral reef record of sea level changes, Mururoa atoll (Tuamotu archipelago, French Polynesia). Palaeogeography, Palaeoclimatology, Palaeoecology 175, 325-341.

Chadwick Jr., W.W., Clague, D.A., Embley, R.W., Perfit, M.R., Butterfield, D.A., Caress, D.W., Paduan, J.B., Martin, J.F., Sasnett, P., Merle, S.G., Bobbitt, A.M., 2013. The 1998 eruption of Axial Seamount: New insight on submarine lava flow emplacement from highresolution mapping.Geochemistry, Geophysics, Geosystems 14, 3939-3968.

Chorowicz, J., 2005. The East African rift system. Journal of African Earth Sciences 43, 379410.

Coffin, M. F., Rabinowitz, P. D., 1987. Reconstruction of Madagascar and Africa: evidence from the Davies Fracture Zone and Western Somali Basin. Journal of Geophysical Research 92, 9385-9406

Cole, J. W., Milner, D. M., Spinks, K. D., 2005. Calderas and caldera structures: a review. Earth-Science Reviews 69, 1-26. 
Courgeon, S., Bourget, J., Jorry, S.J.,2016a. The Malita intra-shelf basin (Bonaparte Basin, NW Australia) - A Plio-Quaternary analogue for ancient epireic carbonate settings. AAPG Bulletin 100, 565-595.

Courgeon, S., Jorry, S.J., Camoin, G.F., BouDagher-Fadel, M.K., Jouet, G., Révillon, S., Bachèlery, P., Pelleter, E., Borgomano, J., Poli, E., Droxler, A.W., 2016b. Growth and demise of Cenozoic isolated carbonate platforms: New insights from the Mozambique Channel seamounts (SW Indian Ocean). Marine Geology 380, 90-105.

Darwin, C., 1842. The structure and distribution of coral reefs

Deschamps, A., Grigné, C., Le Saout, M., Soule, S. A., Allemand, P., Vliet-Lanoe, V.,Floc'h, F., 2014. Morphology and dynamics of inflated subaqueous basaltic lava flows. Geochemistry, Geophysics, Geosystems 15, 2128-2150.

DiCaprio, L., Müller, R. D., Gurnis, M., 2010. A dynamic process for drowning carbonate reefs on the northeastern Australian margin. Geology 381, 11-14.

Dunham, R.J., 1969.Early vadose silt in Townsend mound (reef), New Mexico. In: Depositional Environments in carbonate rocks. (Ed. G. M. Friedman). Spec. Publs. Soc. econ. Paleonr. Miner., Tulsa, 14, 139-181.

Fernandez-Mendiola, P.A., Garcia-Mondejar, J., 2003. Carbonate platform growth influenced by contemporaneous basaltic intrusions (Albian of Larrano, Spain). Sedimentology 50, 961978.

Eberli, G.P., Anselmetti, F.S., Isern, A.R. \& Delius, H., 2010. Timing of changes in sea-level and currents along Miocene Platforms on the Marion Plateau, Australia. In: Cenozoic 
Carbonate Systems of Australia (Ed. by Morgan W.A., George A.D., Harris P.M., J.A. Kupecz\& J.F. Sarg),SEPM Spec. Publ. 95, 219-242. SEPM, Tulsa, OK

Flügel, E., 1982. Case Histories. In Microfacies Analysis of Limestones (pp. 556-580). Springer Berlin Heidelberg.

Flügel, E., 1988.Halimeda: paleontological record and palaeoenvironmental significance. Coral Reefs 6, 123-130.

Fornari, D.J., 1986. Submarine lava tubes and channels. Bulletin of Volcanology 48. 291-298.

Franke, D., Jokat, W., Ladage, S., Stollhofen, H., Klimke, J., Lutz, R., Mahanjane, E.S., Ehrhardt, A.,Schreckenberger, B., 2015. The offshore East African Rift System: Structural framework at the toe of a juvenile rift. Tectonics 34, 2086-2104.

Gaina, C., Torsvok, T.H., Hinsbergen, D.J.J., Medvedev, S., Werner, S.C., Labails, C., 2013. The African Plate: A history of aceanic crust accretion and subduction since the Jurassic. Tectonophydics 604, 4-25.

Godet, A., 2013. Drowning unconformities: palaeoenvironmental significance and involvement of global processes. Sedimentary Geology 293, 45-66.

Gregg, T.K.P., Fink, J.H., 1995.Quantification of submarine lava-flow morphology trough analog experiments.Geology 23, 73-76.

Guillaume, M.M.M., Reyss, J.-L., Pirazzoli, P.A., Bruggemann, J.H., 2013. Tectonic stability since the last interglacial offsets the Glorieuses Islands from the nearby Comoros archipelago. Coral Reefs 32, 719-726. 
Hall-Spencer, J. M., Rodolfo-Metalpa, R., Martin, S., Ransome, E., Fine, M., Turner, S. M., Rowley, S.J., Tedesco, D., Buia, M. C., 2008. Volcanic carbon dioxide vents show ecosystem effects of ocean acidification. Nature 454, 96-99.

Hallock, P., Glenn, E.C., 1986. Larger Foraminifera: A Tool for Paleoenvironmental Analysis of Cenozoic Carboate Depositional Facies. Palaios 1, 55-64.

Hallock, P., and Schlager, W, 1986. Nutrient excess and the demise of coral reefs and carbonate platforms.Palaios 1, 389-398.

Halliday, W.R., 2007. Pseudokarst in the 21st century.Journal of Cave and Karst studies 69. 103-113.

Houghton, B. F., White, J. D., \& Van Eaton, A., 2015. Phreatomagmatic and related eruption styles , in: Sigurdsson, H., Houghton, B., McNutt, S.R., Rymer, H., Stix, J., (Eds.), The Encyclopedia of Volcanoes, Second Edition,Elsevier,USA,537-552.

Houk, P., 2011. Volcanic Disturbances and Coral Reefs. In Encyclopedia of Modern Coral Reefs, Springer Netherlands.pp. 1138-1140

Jorry, S., 2014. PTOLEMEE cruise, RV L'Atalante. http://dx.doi.org/10.17600/14000900

Jorry, S.J., Camoin, G.F., Jouet, G., Le Roy, P., Vella, C., Courgeon, S., Prat, S., Paumard, V., Boulle, J., Caline, B. and Borgomano., J., 2016. Modern sediments and Pleistocene reefs from isolated carbonate platforms (Iles Eparses, SW Indian Ocean): A preliminary study.ActaOecologica 72, 129-143

Jorry,S.J., Davaud, E., Caline, B. 2003. Controls on the distribution of nummulitefacies: A case study from the late Ypresian El Garia Formation (Kesra Plateau, Central Tunisia). Journal of Petroleum Geology 26(3), 283-306. 
Jouet, G., Deville, E., 2015. PAMELA-MOZ04 cruise, RV Pourquoi Pas ?. http://dx.doi.org/10.17600/15000700

Kusky, T.M., Toraman, E., Raharimahefa, T., Rasoazanamparany, C., 2010. Active tectonics of the Alaotra-AnkayGraben System, Madagascar: possible extension of Somalian-African diffusive plate boundary?. Gondwana Research 18, 274-294.

Langmann, B., Zakšek, K., Hort, M., Duggen, S., 2010. Volcanic ash as fertiliser for the surface ocean. Atmospheric Chemistry and Physics 10, 3891-3899.

Lehrmann, D.J., Donghong, P., Enos, P., Minzoni, M., Ellwood, B.B., Orchard, M.J., Jiyan, Z., Jiayong, W., Dillett, P., Koenig, J., Steffen, K., Druke, D., Druke, J., Kessel, B., Newkirk, T., 2007. Impact of differential tectonic subsidence on isolated carbonate-platform evolution: Triassic of the Nanpanjiang Basin, south China. Americain Association of Petroleum Geologist Bulletin 91, 287-320.

Lincoln, J.M., Schlanger, S.O.,1987. Miocene sea-level falls related to the geologic history of Midway Atoll. Geology 15, 454-457.

Lincoln, J.M., Schlanger, S.O., 1991. Atoll stratigraphy as a record of sea level change: problems and prospects. Journal of Geophysical Research: Solid Earth 96, 6727-6752.

Lü, C., Wu, S., Yao, Y., Fulthorpe, C.S., 2013. Development and controlling factors of Miocene carbonate platform in the Nam Con Son Basin, southwestern South China Sea. Marine and Petroleum Geology 45, 55-68.

Mangini, A., Halbach, P., Puteanus, D., Segl, M., 1987. Chemistry and growth history of central Pacific Mn crusts and their economic importance,Marine Minerals, 205-220. 
Martin, U., Breitkreuz, C., Egenhoff, S., Enos, P., Jansa, L., 2004. Shallow-marine phreatomagmatique eruptions through a semi-solidified carbonate platform (ODP Leg 144, site 878, Early Cretaceous, MIT Guyot, West Pacific). Marine Geology 204, 251-272.

McArthur, J. M., Howarth,R. J. et al., 2012. Chapter 7 - Strontium Isotope Stratigraphy.The Geologic Time Scale 2012, Boston, Elsevier, 127-144.

McClinton, J. T., \& White, S. M. (2015). Emplacement of submarine lava flow fields: A geomorphological model from the Niños eruption at the Galápagos Spreading Center. Geochemistry, Geophysics, Geosystems16, 899-911.

McGregor, D., 2015. History of the development of the East African Rift System: A series of interpreted maps through time.Journal of African Earth Sciences 101, 232-252.

Menier, D., Pierson, B., Chalabi, A., Ting, K.K., Pubellier, M., 2014.Morphological indicators of structural control, relative sea-level fluctuations and platform drowning on present-day and Miocene carbonate platforms. Marine and Petroleum Geology 58, 776-788.

Michon, L., 2016. The volcanism of the Comoros Archipelago integrated at a regional Scale, in: Bachèlery, P., Lénat, J.-F., Di Muro, A., Michon, L. . (Eds.), Active volcanoes of the Soutwest Indian Ocean. Springer-Verlag, the Netherlands 333-344.

Mihaljević, M., Renema, W., Welsh, K., Pandolfi, J. M., 2014. Eocene-Miocene shallowwater carbonate platforms and increased habitat diversity in Sarawak, Malaysia. Palaios29, $378-391$.

Miller, K.G., Kominz, M.A., Browning, J.V., Wright, J.D., Mountain, G.S., Katz, M.E., Sugarman, P.J., Cramer, B.S., Christie-Blick, N., Pekar, S.F., 2005.The phanerozoic record of global sea-level change.Science 310, 1293-1298. 
Murdmaa, I., Nemliher, J., Bogdanova, O., Gorshkov, A., Kallaste, T., Vasilyeva, V., 1995.Ferromanganese and phosphatichardgrounds on the western pacific guyots drilled during legs 143 and 1441. In Proceedings of the Ocean Drilling Program - Scientific results 144. $419-428$

Mutti, M., Hallock, P., 2003. Carbonate systems along nutrient and temperature gradients: some sedimentological and geochemical constraints. International Journal of Earth Sciences $92,465-475$.

Olu, K, 2014. PAMELA-MOZ01 cruise, RV L'Atalante. http://dx.doi.org/10.17600/14001000

Paumard, V., Zuckmeyer, E., Boichard, R., Jorry, S.J., Bourget, J., Borgomano, J., Maurin, T., Ferry, J.N., 2017. Evolution of Late Oligocene-Early Miocene attached and isolated carbonate platforms in a volcanic ridge context (Maldives type), Yadana field, offshore Myanmar. Marine and Petroleum Geology 81. 361-387.

Pomar, L., Bassant, P., Brandano, M., Ruchonnet, C., Janson, X., 2012.Impact of carbonate producing biota on platform architecture: insights from Miocene examples of the Mediterranean region. Earth-Science Reviews, 113, 186-211

Pomar, L., Hallock, P., 2008. Carbonate factories: A conundrum in sedimentary geology. Earth-Science Reviews 87, 134-169.

Pomar, L., Baceta, J. I., Hallock, P., Mateu-Vicens, G., Basso, D., 2017. Reef building and carbonate production modes in the west-central Tethys during the Cenozoic. Marine and Petroleum Geology 83, 261-304.

Prat S., Jorry S.J., Jouet G., Camoin G.F., Vella C., Le Roy P., Caline B., Boichard R., Pastol Y., 2016. Geomorphology and sedimentology of a modern isolated carbonate platform: The glorieuses archipelago, SW Indian Ocean. Marine Geology 380. 272-283. 
Reuter, M., Piller, W. E., Richoz, S., 2012. The dispersal of Halimeda in northern hemisphere mid-latitudes: Palaeobiogeographical insights. Perspectives in Plant Ecology, Evolution and Systematics14, 303-309.

Salman, G., Abdula, I., 1995. Development of the Mozambique and Ruvuma sedimentary basins, offshore Mozambique, Sedimentary Geology 96, 7-41

Sattler, U., Immenhauser, A., Schlager, W., Zampetti, V., 2009. Drowning history of a Miocene carbonate platform (Zhujiang Formation, South China Sea). Sedimentary Geology 219, 318-331.

Schlager, W., 1981.The paradox of drowned reefs and carbonate platforms.Geological Society of America Bulletin 92, 197-211.

Schlager, W., 1989. Drowning unconformities on carbonate platforms. in Controls on Carbonate Platformand Basin Development, SEPM Special Publications 44.

Schlager, W., 2003. Benthic carbonate factories of the Phanerozoic. International Journal of Earth Sciences 92, 445-464.

Schlager, W. (2005). Carbonate sedimentology and sequence stratigraphy (No. 8). SEPM Soc for Sed Geology.

Schlager, W., Purkis, S. J., 2013. Bucket structure in carbonate accumulations of the Maldive, Chagos and Laccadive archipelagos. International Journal of Earth Sciences 102, 2225-2238. 
Stamps, D. S., Iaffaldano, G., Calais, E., 2015. Role of mantle flow in Nubia-Somalia plate divergence. Geophysical Research Letters 42, 290-296.

Staudigel, H., Clague, D.A., 2010. The geological history of deep-sea volcanoes: Biosphere, hydrosphere, and lithosphere interactions. Oceanography 23, 58-71.

Storey, M., Mahoney, J.J., Saunders, D., Dunca, R.A., Kelley, S.P., Coffin, M.F., 1995. Timing of hot spot-related volcanism and the breakup of Madagascar and India. Science 267, 852

Tomascik, T., Van Woesik, R., Mah, A. J., 1996.Rapid coral colonization of a recent lava flow following a volcanic eruption, Banda Islands, Indonesia. Coral Reefs 15, 169-175.

Toomey, M., Ashton, A.D., Perron, J.T., 2013. Profiles of ocean islands coral reefs controlled by sea-level history and carbonate accumulation rates. Geology 41, 731-734.

Toomey, M. R., Ashton, A. D., Raymo, M. E., Perron, J. T., 2016.Late Cenozoic sea level and the rise of modern rimmed atolls. Palaeogeography, Palaeoclimatology, Palaeoecology 451, 73-83.

Torsvik, T. H., Tucker, R. D., Ashwal, L. D., Carter, L. M., Jamtveit, B., Vidyadharan, K. T., \&Venkataramana, P., 2000. Late Cretaceous India-Madagascar fit and timing of break-up related magmatism. Terra Nova12, 220-224

Uematsu, M., Toratani, M., Kajino, M., Narita, Y., Senga, Y., Kimoto, T., 2004. Enhancement of primary productivity in the western North Pacific caused by the eruption of the Miyake-jima Volcano. Geophysical research letters $31.6 \mathrm{p}$. 
Van Waasbergen, R. J., Winterer, E. L.,1993. Summit geomorphology of western Pacific guyots. The Mesozoic Pacific: Geology, Tectonics, and Volcanism, 335-366.

Webster, J. M., Braga, J. C., Clague, D. A., Gallup, C., Hein, J. R., Potts, D. C., Renema, W., Riding, R., Riker-Coleman, K., Silver, E., Wallace, L. M., 2009. Coral reef evolution on rapidly subsiding margins. Global and Planetary Change 66, 129-148.

White, J. D., Ross, P. S., 2011. Maar-diatreme volcanoes: a review. Journal of Volcanology and Geothermal Research 20, 1-29.

Wilson, M.E.J., 2000. Tectonic and volcanic influences on the development and Diachronous termination of a Tertiary tropical carbonate platform. Journal of Sedimentary Research 70, 310-324.

Wilson, M.E.J., Lokier, S.W., 2002. Siliclastic and volcaniclastic influences on equatorial carbonates: insights from the Neogene of Indonesia. Sedimentology 49, v.583-601.

Wilson, P.A., Jenkyns, H.C., Elderfield, H., Larson, R.L., 1998.The paradox of drowned carbonate platforms and the origin of Cretaceous Pacific guyots.Nature 392, 889- 894

Wright, K. A., Davies, R. J., Jerram, D. A., Morris, J., Fletcher, R., 2012. Application of seismic and sequence stratigraphic concepts to a lava-fed delta system in the Faroe-Shetland Basin, UK and Faroes. Basin Research24, 91-106.

Wu, S., Yang, Z., Wang, D., Lü, F., Lüdmann, T., Fulthorpe, C.S., Wang, B., 2014. Architecture, development and geological control of the Xisha carbonate platforms, northwestern South China Sea. Marine geology 350, 71-83. 
Yamagishi, H., 1991. Morphological and sedimentological characteristics of the Neogene submarine coherent lavas and hyaloclastites in Southwest Hokkaido, Japan, Sedimentary Geology 74, 5-23.

Zachos, J., Pagani, M., Sloan, L., Thomas, E., \&Billups, K., 2001.Trends, rhythms, and aberrations in global climate 65 Ma to present. Science, 292, 686-693.

\section{Captions}

Figure 1: (A) Physiography of the Mozambique Channel (GEBCO 2014, 100m resolution). Green squares correspond to Eparses Islands. Ba. means Bassas da India. Eu. means Europa. Glo. means Glorieuses. Black dashed line correspond to the Davie Ridge. Study area is indicated by a black rectangle. (2) Bathymetry DEM (20m resolution) of the study area. White lines correspond to fault and structural lineaments. Red lines and lettering correspond to seismic profiles shown in Figure 2. Dark blue rectangles locate geomorphological close-ups presented in Figure 7. Yellow and blacks stars and lettering indicate the approximate location of dredge operations.

Figure 2: Fast (Low resolution) seismic profiles and associated interpretations. (A) MOZ4SR198 (Hall Bank, see location on Figures 1 \& 5A). (B) PTOLEMEE-SR68 (Jaguar Bank, see location on Figures $1 \&$ 5B). (C) (A) PTOLEMEE-SR65 (Bassas da India, see location on Figures $1 \& 5 C)$. Pink arrows correspond to seismic reflections terminations. Red lines correspond to faults. Green line corresponds to the seafloor. Pink lines in (B) correspond to seismic artifact. Art. means seismic artifact. 
Figure 3: High resolution seismic profiles and associated interpretations. (A) PTOLEMEEHR52 (Hall Bank, see location on figure 5A). (B) PTOLEMEE-HR56 (Hall Bank, see location on figure 7A). (C) PTOLEMEE-HR53 (Hall Bank, see location on figure 5A). (C) PTOLEMEE-HR32 (Jaguar Bank, see location on figure 5B). Pink arrows correspond to seismic reflections terminations. Red dashed lines correspond to faults. Green line corresponds to the seafloor

Figure 4: PTOLEMEE-HR59 (Bassas da India), high resolution seismic profile and associated interpretation. See location on Figure 5C. Red lines correspond to faults. Green line corresponds to the sea-floor. Pink arrows correspond to seismic reflections terminations.

Figure 5: High resolution (10m) bathymetry DEMs.(A) Hall Bank, (B) Jaguar Bank and (C) Bassas da India. See location in Figure 1. Black lines and lettering correspond to seismic profiles. Pink lines and lettering correspond to location of dredge operations. Red lines correspond to fault escarpments. Dashed red lines correspond faults inferred both from bathymetry DEMS and seismic lines. White rectangles correspond to geomorphological closeups presented in Figures 6A \& 7A. In (C), thick black dashed line corresponds to the boundary of sand ridges and gullies morphologies. Thin black dashed lines correspond to the crests of these sedimentary features.

Figure 6: (A) Very high resolution (5m) bathymetry DEM illustrating a lobate lava flow complex on top of the Jaguar Bank (sea location in Figure 5B).Submarine pictures of the sea floor. (B) Bright and flat rocky outcrops interpreted as carbonate slabs. (C) \& (D) fractured, rugged and very dark outcrops interpreted as lobate lava flows. Location of the pictures is indicated on A (red squares).

Figure 7: (A) Very high resolution $(5 \mathrm{~m})$ bathymetry DEM illustrating a rounded and flat-top depression on top of the Hall Bank. This morphology is interpreted as a phreatomagmatic 
crater (see details in the text). Red squares and lettering correspond to location of submarine pictures presented in Figure 7B \& 7D. (B) Submarine picture of a pebble field. (C) Pebbles encrusted by Fe-Mn crusts and collected in the NE sector of the Hall Bank (MOZ1-DW05, see location on Figure 5A). (D) Submarine picture of a very dark outcrop interpreted as volcanic.

Figure 8: (A) High resolution (10m) bathymetry DEM illustrating the geomorphology of the Jaguar Bank summit (see location in Figure 1). White dashed lines correspond to fault escarpments. Pink lines and lettering correspond to location of dredge operation. (B) Halimeda (Ha) grainstone and coral (Co) boundstone collected along the carbonate build-up morphology (MOZ4-DR06).

Figure 9: (A) PTOLEMEE-SR106, fast seismic profile (see location on figure 9B). Black lines correspond to faults. Green line corresponds to the approximate boundary between the volcanic ridge and adjacent deposits. (B) Slope map (20m resolution) of the study area extended towards NE. Red lines represent the SW-NE normal fault networks affecting the seamounts and the adjacent basinal deposits.

Figure 10:Thin sections micrographs of rock samples collected along carbonate platform flanks (see dredge location on Figures 1, 5 \& 8).(A) MOZ01-DR18-01: Skeletal Packstone with large encrusted corals (B) MOZ04-DR18-02: Skeletal grainstone of LBF and Halimeda sp. (C, D) MOZ04-DR05-01: Skeletal packstone of LBF and Halimeda with large encrusted corals. (E) MOZ01-DR20-01: Skeletal packstone, close up (F) illustrates moldic porosity geopetally infilled by crystalline silty sediments (crystal silts). (G) MOZ1-DR20-02: Skeletal Packstone. RA: red algae; Co: coral; EF: encrusting foraminifera;Ga: Gastropods; Br: Bryozoans;VF: Volcanic fragment; Te: Textularidae; LBF: large benthic foraminifera; Cy: Cycloclypeus; Lp: Lepidocyclina; Mio: Miogypsina; Ka: Katacycloclypeus; Op: Operculina; 
Am: Amphistegina; Sp: Sphaerogypsina; Miol: Miolepidocyclina excentrica, Vi: Victoriella sp.; Planktonic foraminifera: PF

Figure 11: Thin sections micrographs of rock samples collected along carbonate platform tops (see dredges location on Figures 1 \& 5). (A) MOZ01-DW05-C1: Packstone of planktonic foraminifera including dolomitized coral-rich limestone. Perf.: perforation features. (B) MOZ01-DW05-C2c: Phosphatized packstone of planktonic foraminifera including volcanic clasts and covered by tuff. Volcaniclastic deposits include carbonate fragments (blue arrows). (C) MOZ04-DN02-02d: Phosphatized packstone of planktonic foraminifera including large reworked coralgal fragments. In (B, C), white arrows indicate brownish and beige concretions and crusts that correspond to phosphatization features. (D) Dolomitized grainstone reworked into wackestone of planktonic foraminifera. (E) MOZ01DW05-10: Volcanic tuff including armored lappilli (AL, red arrows indicate dark layers coating lappilli, see details in the text) and large carbonate fragment (white rectangle and associated close-up). (F) Fractured and altered lava infilled first by wackestone of planktonic foraminifera (MOZ4-DR08-01b). A second fracture network is infilled by phosphatized packstone of planktonic foraminifera (G, MOZ04-DR08-01a) marked by abundant shallowwater carbonate grains. Co: coral; Bi: Bivalve; RA: red algae; Am: Amphistegina; Mio: Miogypsina; Ha: Halimeda; Mi: Milliolids; Planktonic foraminifera: PF; Ol: Olivine mineral.

Figure 12:(A) Hypothetical schema of south Mozambique Channel isolated carbonate platforms architectures. (B) Simplified schemas of the Neogene evolution of south Mozambique Channels isolated carbonate platforms. Not to scale.

Table 1: Synthesis of dating and microfacies analysis. PF: Planktonic Foraminifera; RA: Red Algae; LBF: Larger Benthic Foraminifera. 
Figure 1

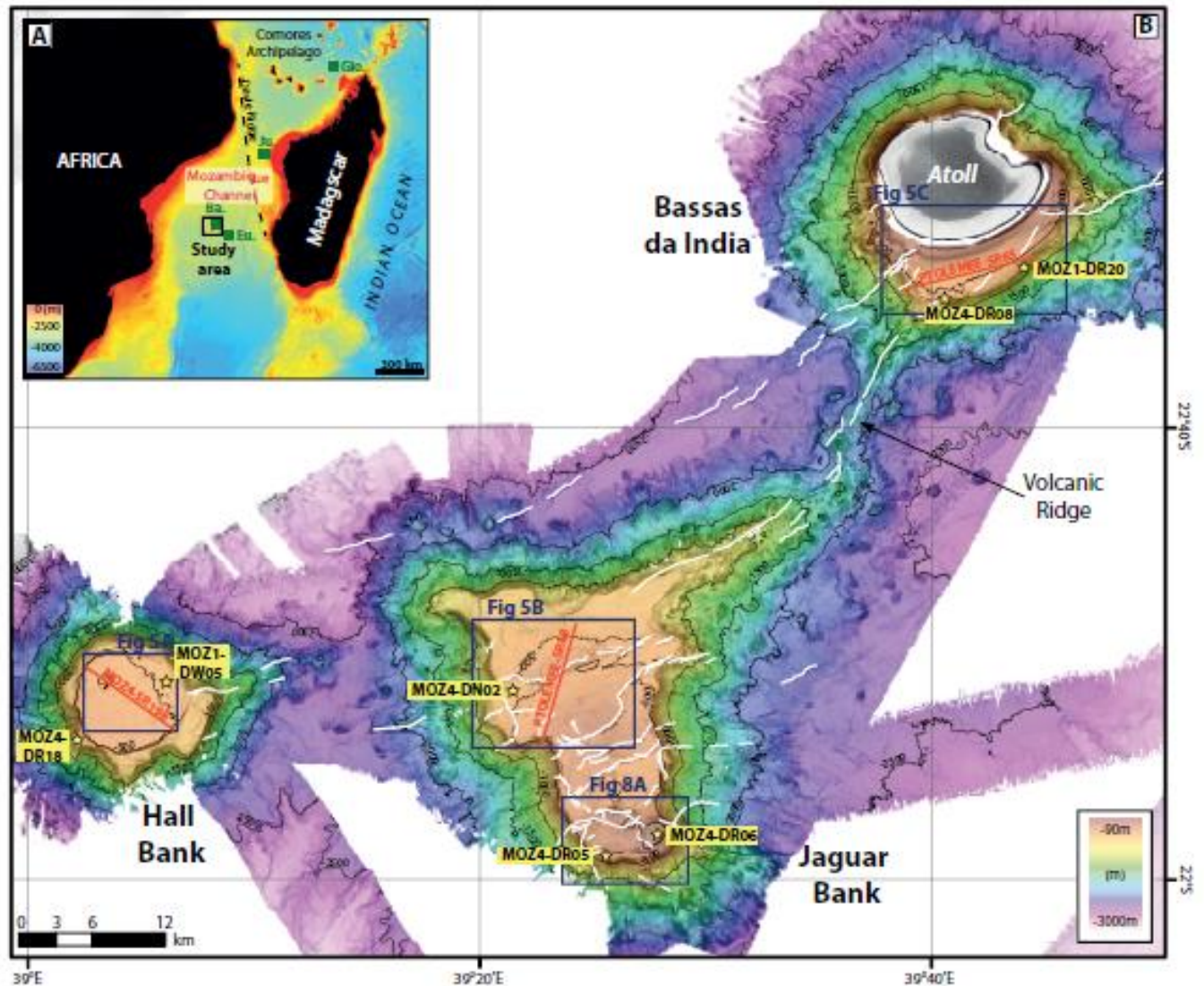


Figure 2
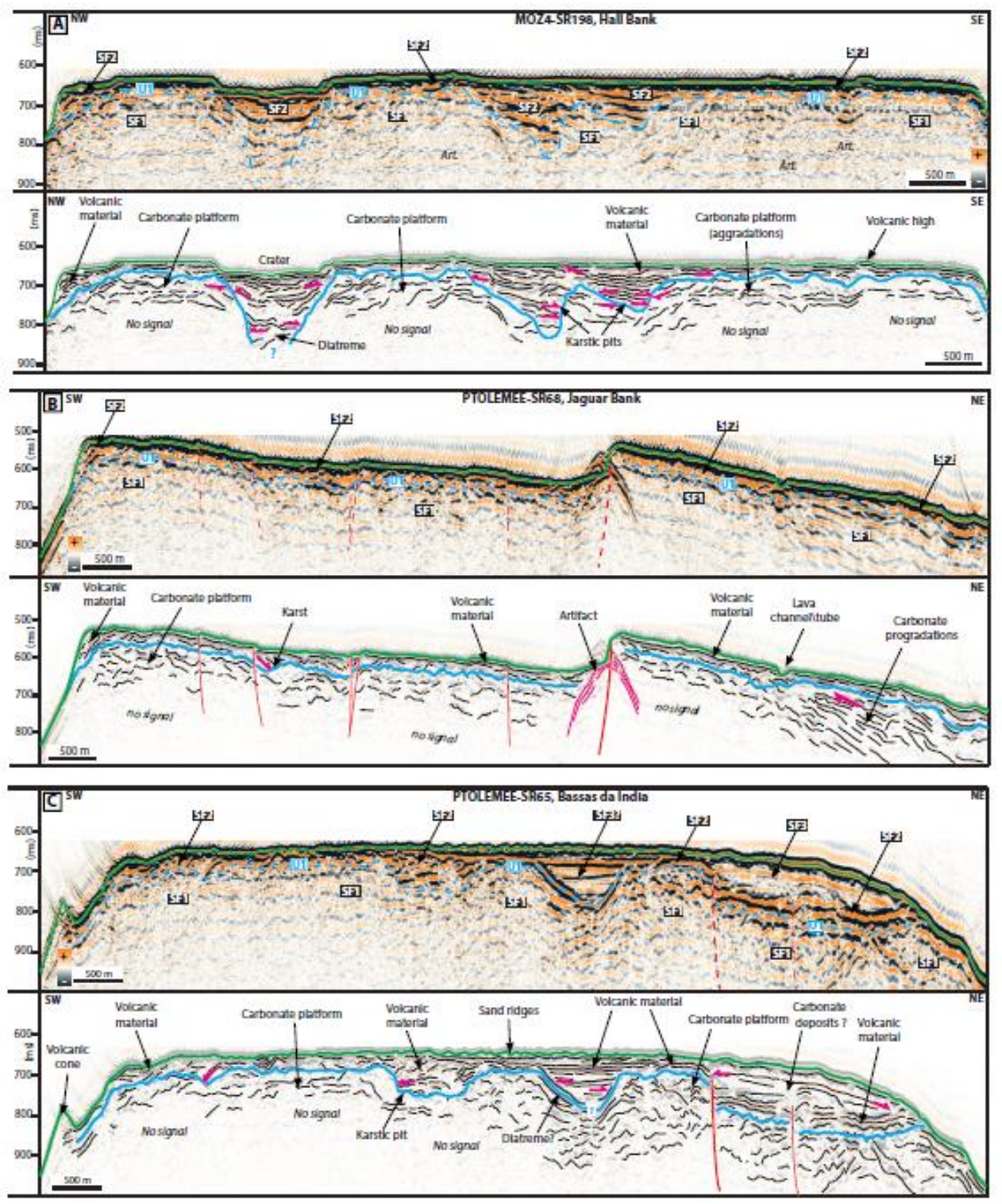

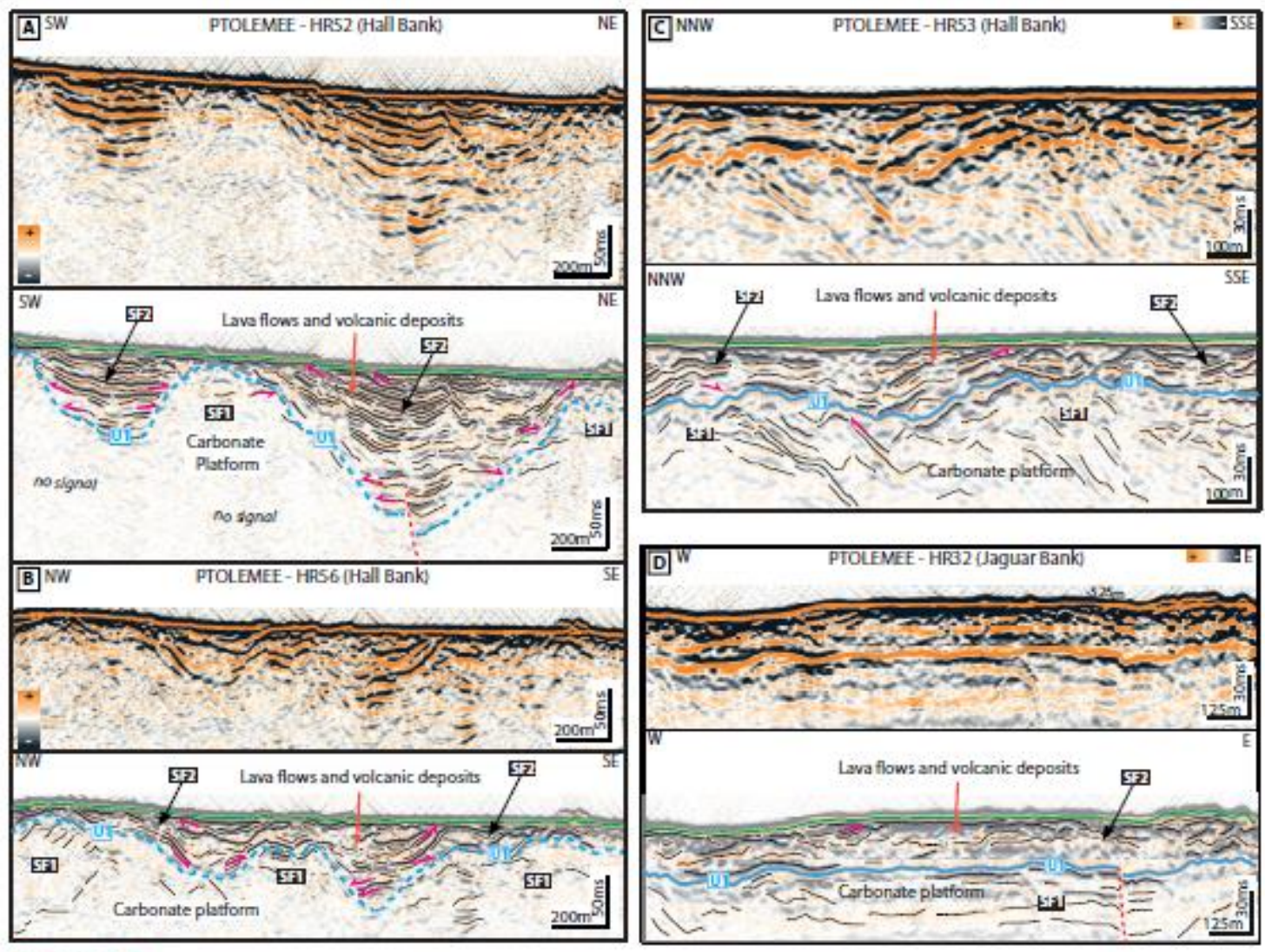

Figure 3 


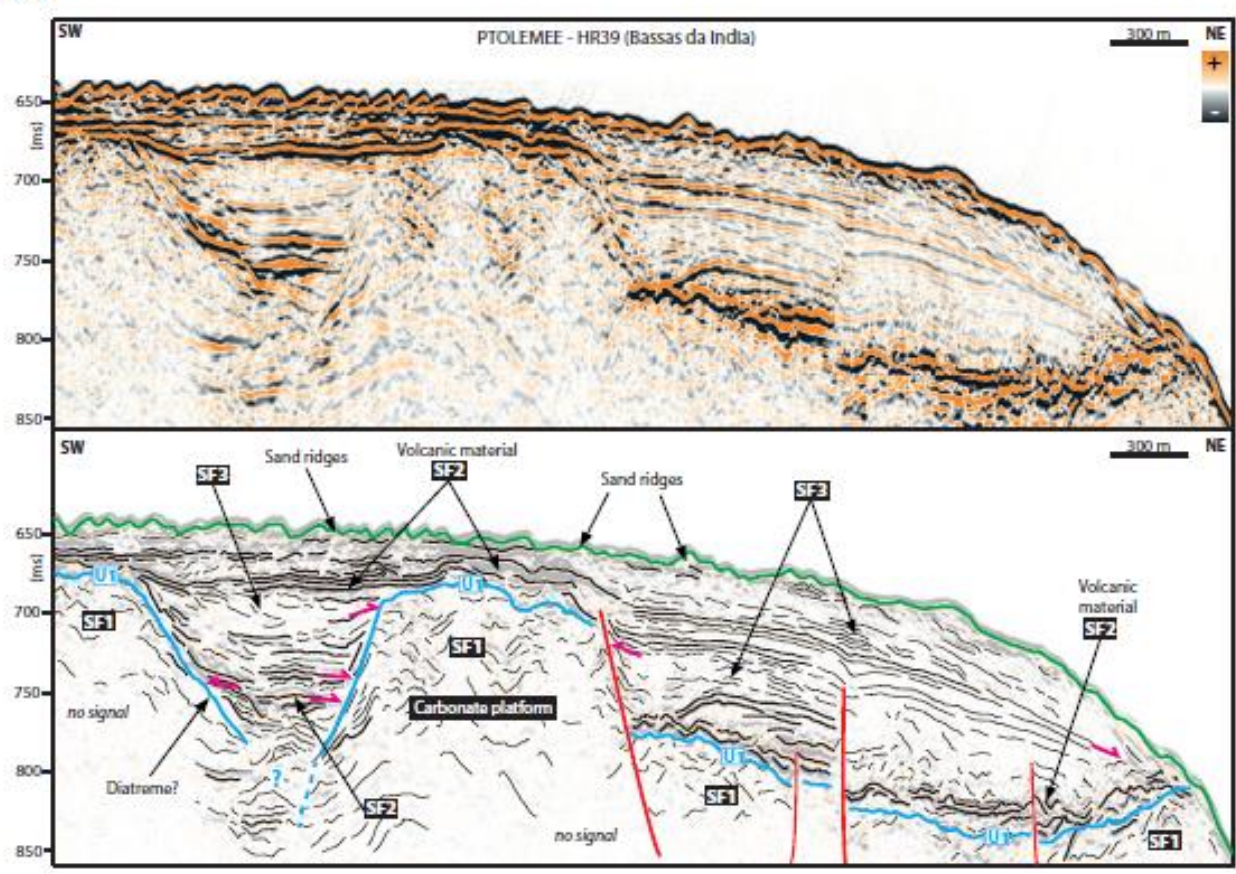


Figure 5
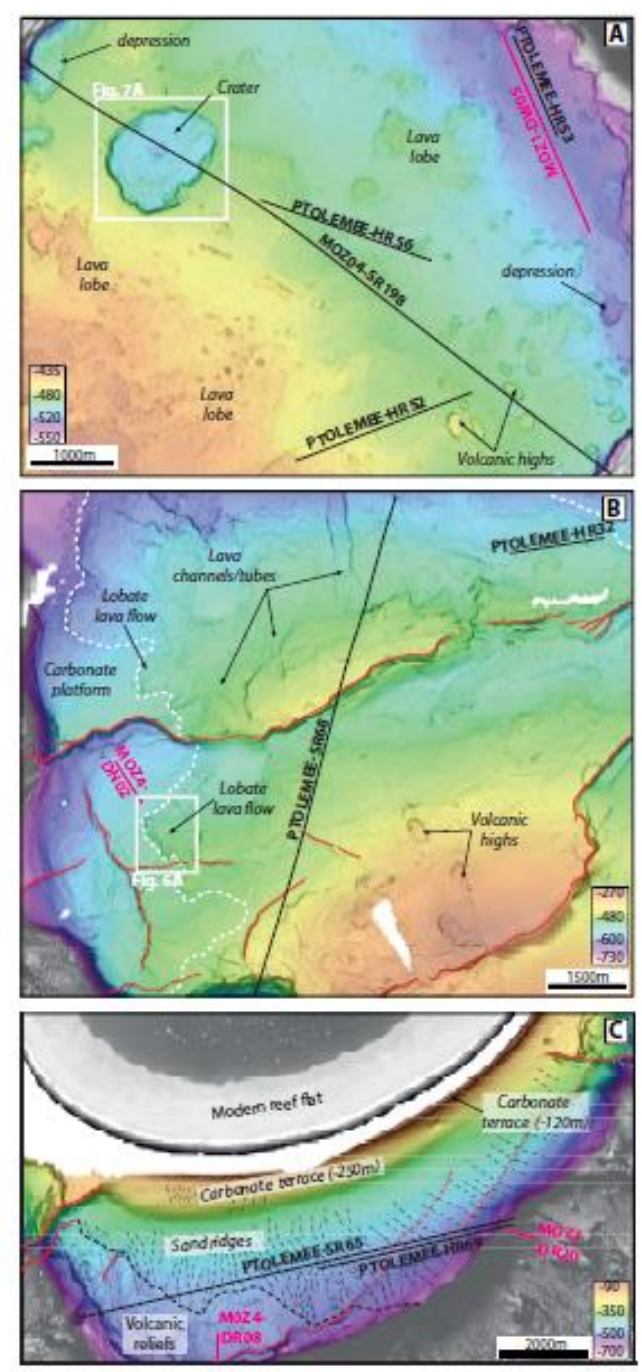
Figure 6

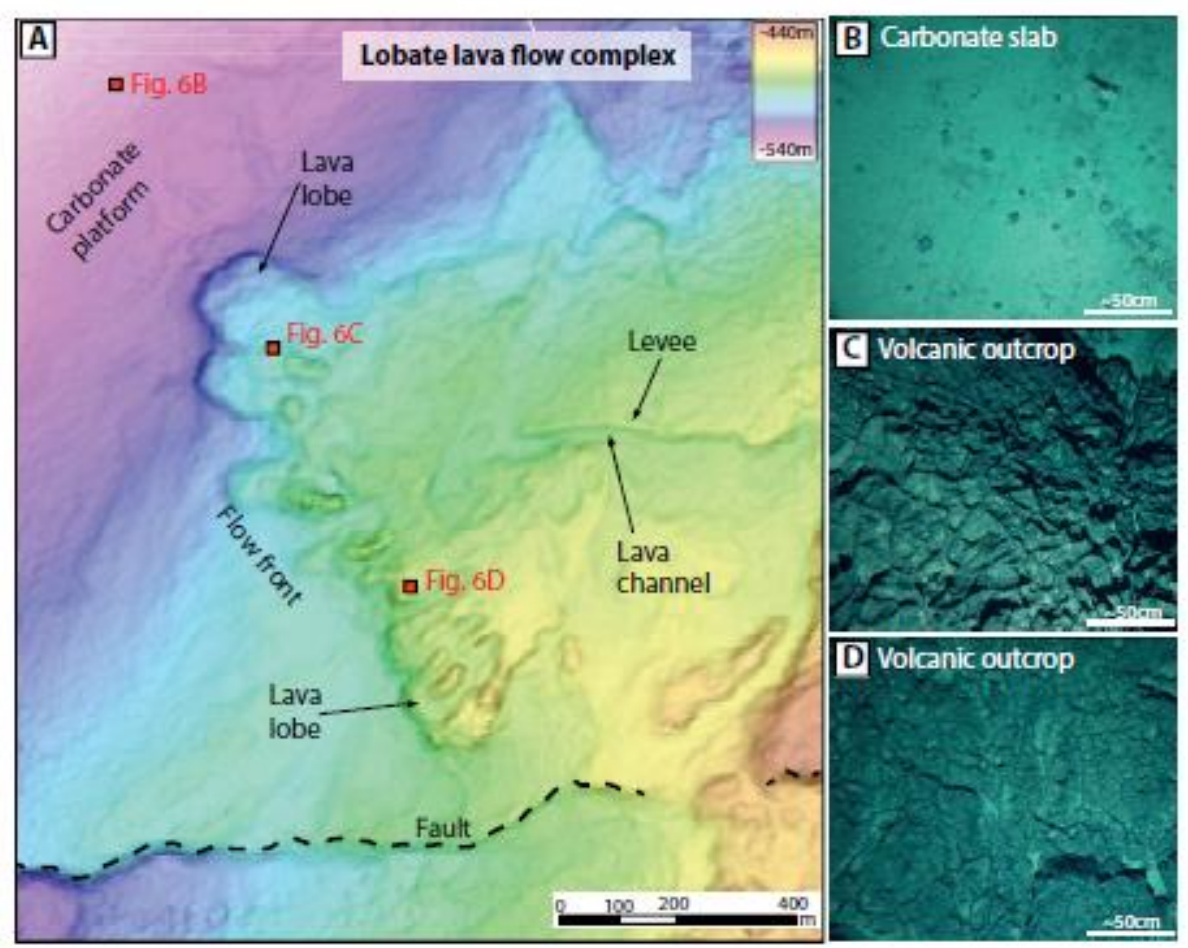


Figure 7

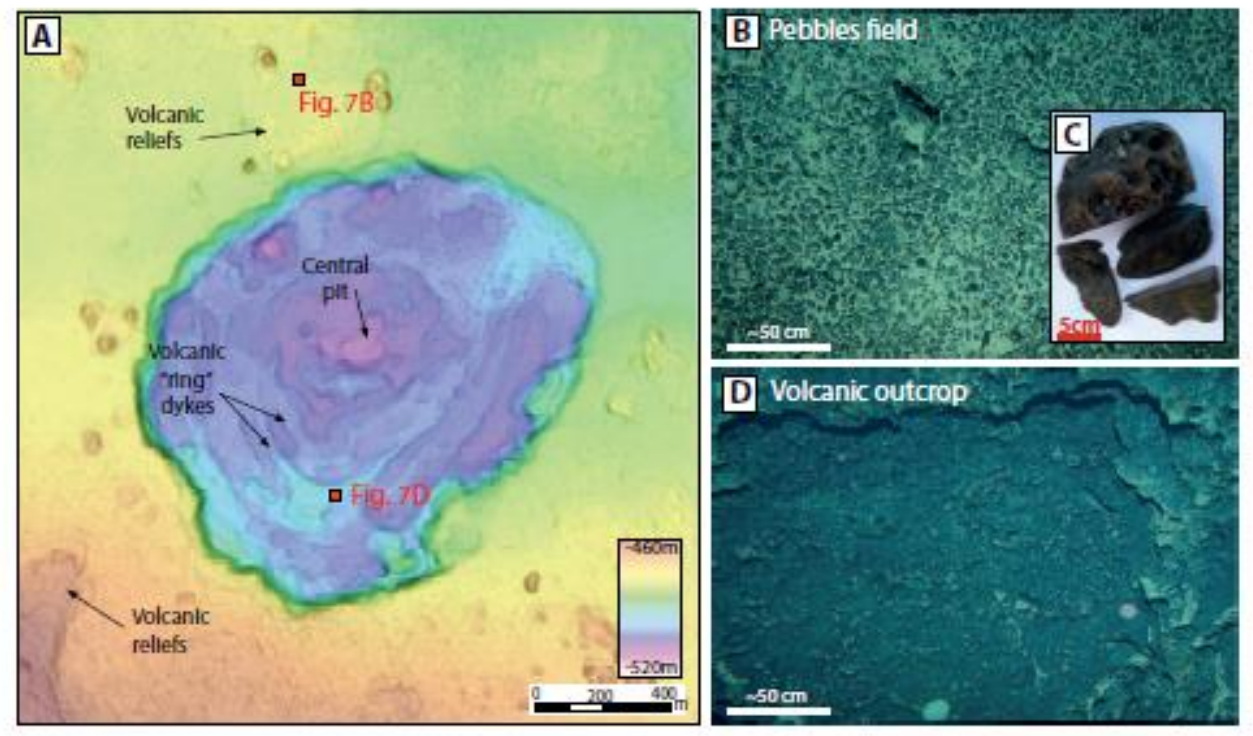


Figure 8

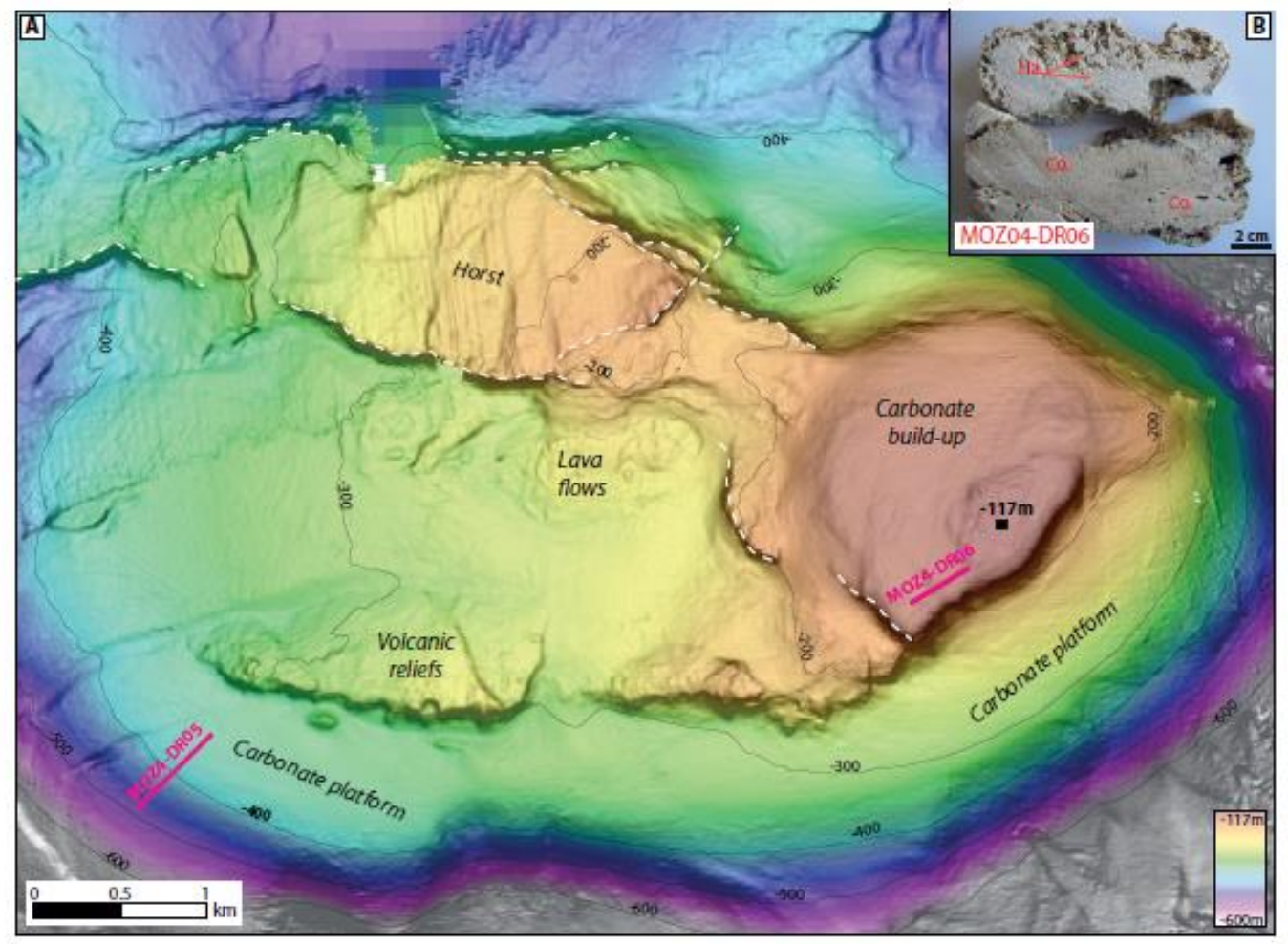




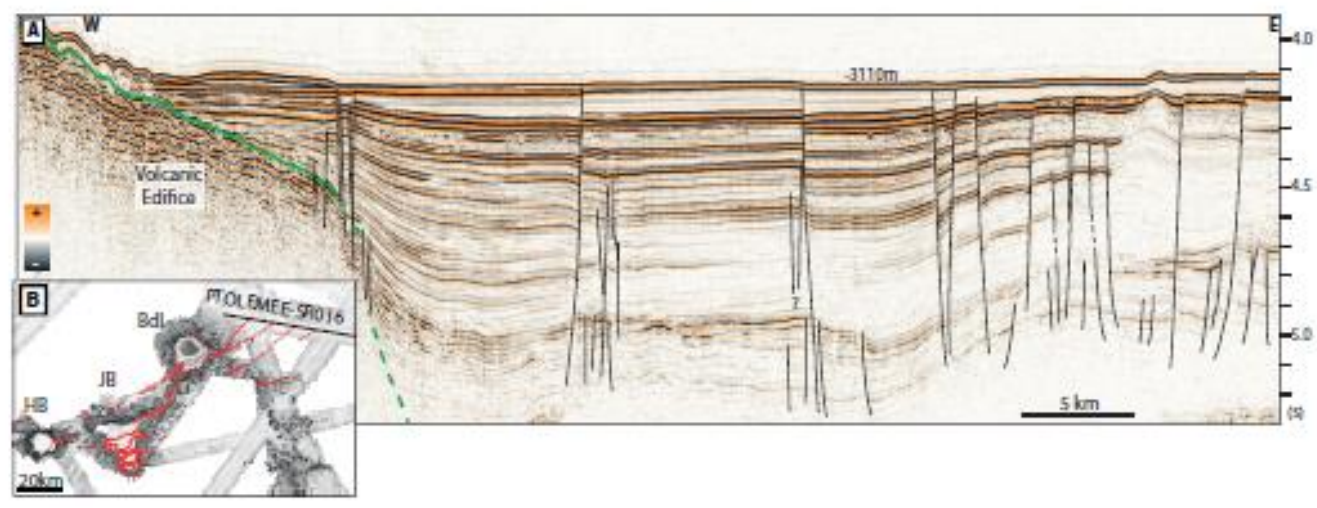


Figure 10

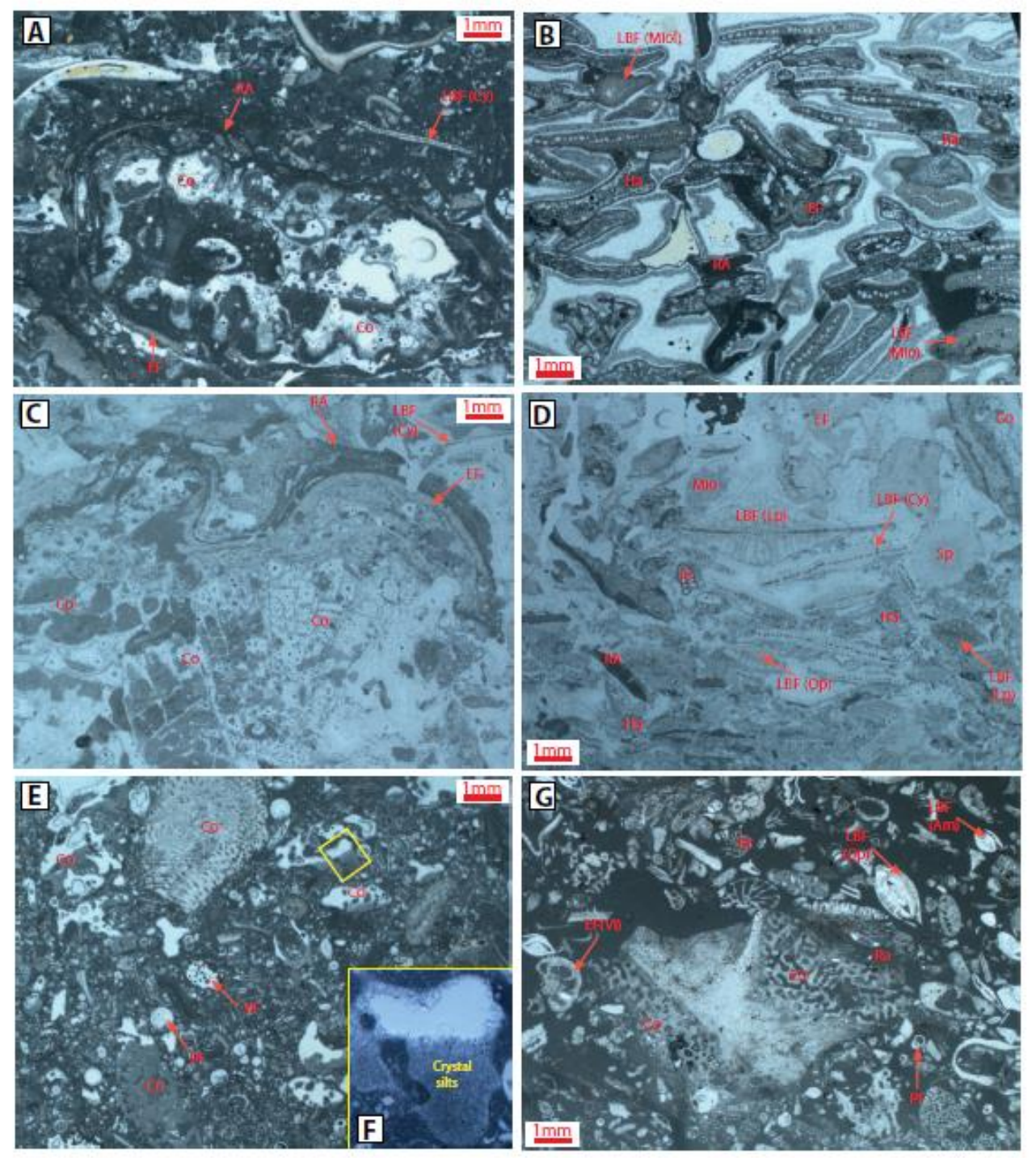


Figure 11
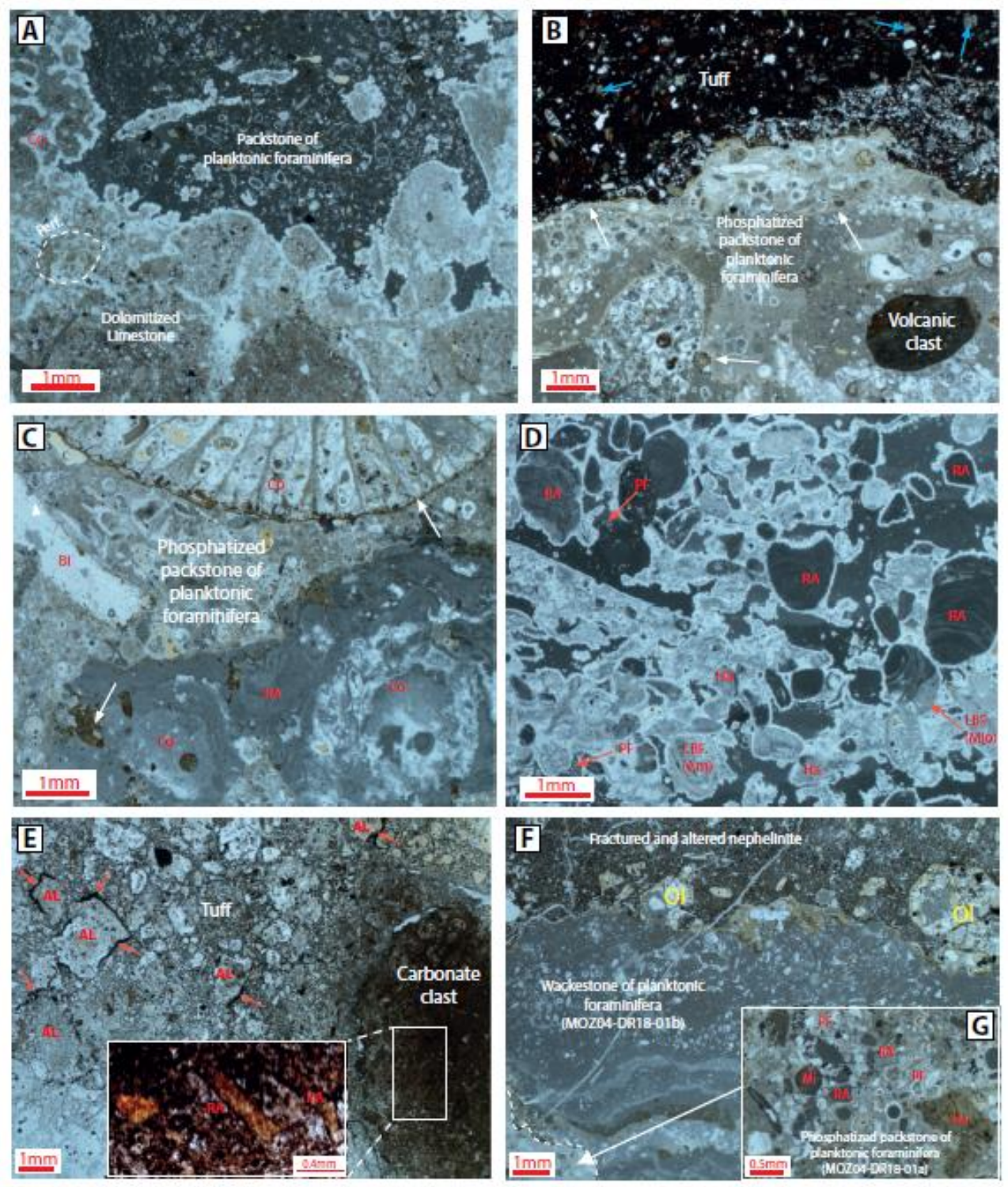


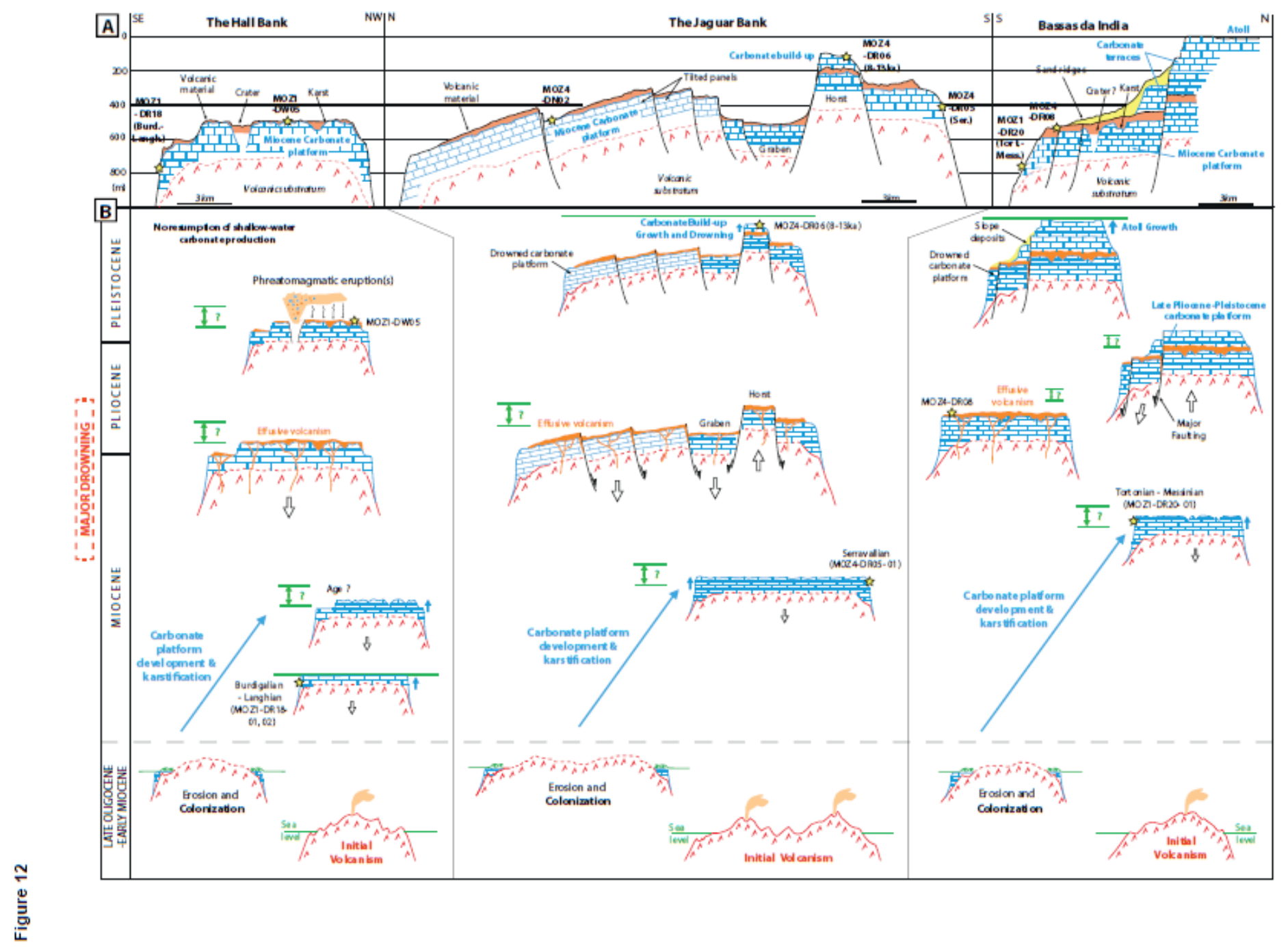




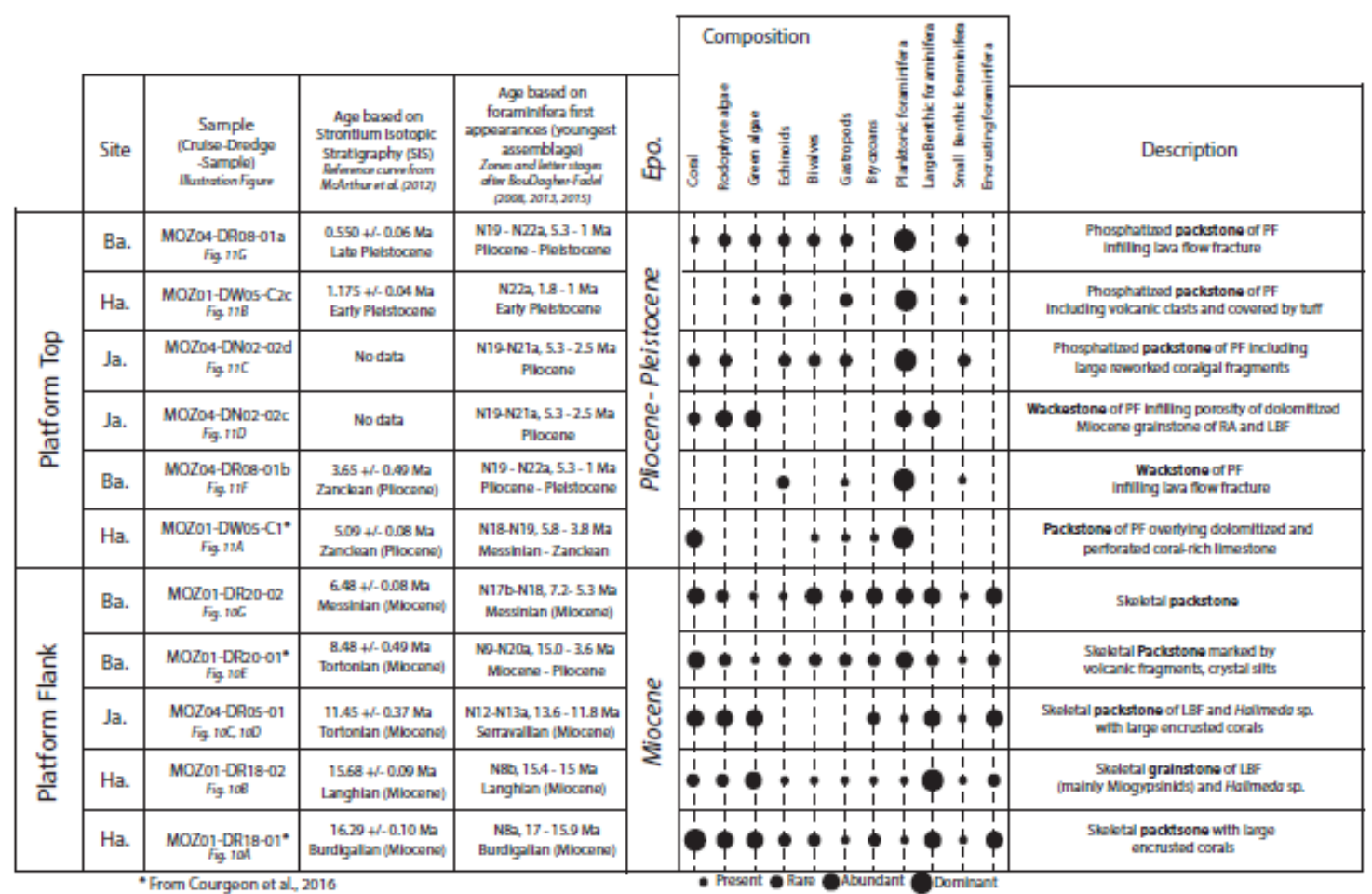

Table 1 